\title{
CANCIÓN TRISTE DE SAN VICENTE DE FRÍAS
}

\begin{abstract}
Marina Aurora Garzón Fernández
Universidade de Santiago de Compostela

Data recepción: 2018/06/10

Data aceptación: 2018/12/19

Contacto autora: marina.garzon.fernandez@usc.es

ORCID: https://orcid.org/0000-0001-8472-218X

RESUMEN

La portada esculpida de la iglesia de San Vicente de Frías (Burgos, s. XIII) fue destruida en 1906 al derrumbarse su torre. Los fragmentos rescatados se encuentran hoy en el Museo de los Claustros de Nueva York, donde fueron instalados en 1932 siguiendo una reconstrucción hipotética de la portada original. Para recuperar este conjunto olvidado por la historiografía del arte hispana, el presente artículo ofrece un análisis histórico-artístico de la iglesia y sus esculturas, así como del proceso de traslado y reconstrucción de la portada. En suma, se propone retrasar la datación actual de la iglesia hasta mediados del siglo XIII, se describen los talleres que participaron en la obra con sus posibles filiaciones y se identifican los principales temas del programa, destacando un ciclo desconocido de la vida de San Millán.
\end{abstract}

Palabras clave: san Vicente de Frías (Burgos), Museo de los Claustros de Nueva York, patrimonio, San Millán de la Cogolla, cultura visual

\section{ABSTRACT}

The sculpted portal of the church of San Vicente de Frías (Burgos, 13th century) was destroyed when the church tower collapsed in 1906. The fragments recovered at the time can now be found at The Cloisters in New York, where they were installed in 1932 as part of a reconstruction of the original portal. In recovering a site forgotten by the historiography of Spanish art, this article offers a historical and artistic analysis of the church and its sculptures, and the process whereby the portal was moved and rebuilt. It proposes a later date for the construction of the church -around the mid13th century- and describes the workshops that took part along with their possible influences. It also identifies the main aspects of the programme, highlighting an unknown cycle in the life of San Millán.

Keywords: San Vincente de Frías (Burgos), The Cloisters (New York), heritage, San Millán de la Cogolla, visual culture

Las esculturas de San Vicente de Frías, expuestas hoy en el Museo de los Claustros de Nueva York en el Alto Manhattan, hunden sus raíces en una pequeña villa a orillas del Alto Ebro en Burgos. La rica portada labrada en el siglo XIII se desmoronó con el derrumbe de la torre en 1906 y sus fragmentos serían vendidos y revendidos en Nueva York hasta ver la luz de nuevo en 1924 en las nuevas colecciones del Museo Metropolitano'.

La distancia que separa ahora estas esculturas de su cuna burgalesa las relegó a un olvido historiográfico, exceptuando escuetas menciones en el Boletín del Museo Metropolitano, el Catálogo del Museo de los Claustros y la Enciclopedia del Románico un estudio exhaustivo de la obra ha im- 

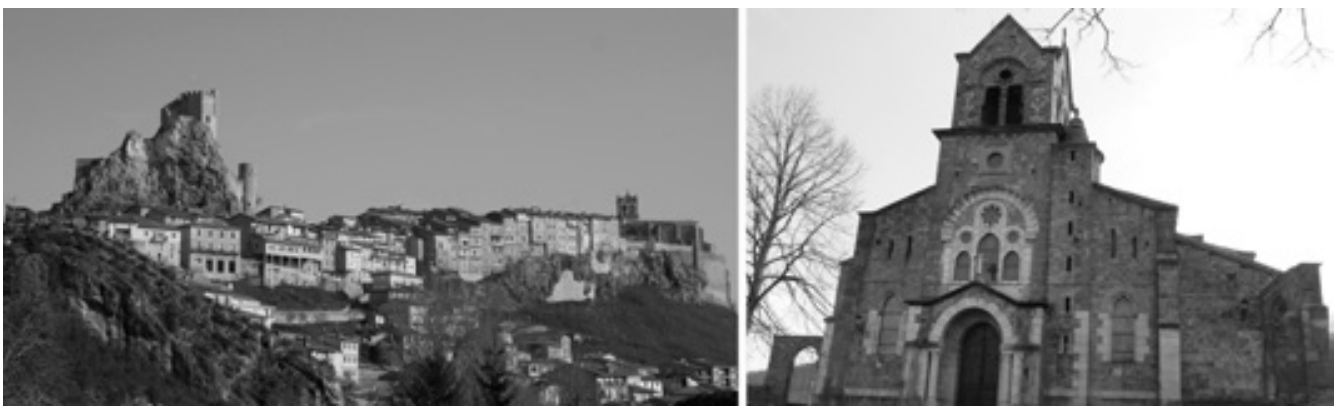

Fig. 1. Vista de la Ciudad de Frías. Iglesia de San Vicente. Frías (Burgos). Fotos de Ignacio Mascuñán Freijanes

pedido su correcta contextualización, excluyendo de obras compilatorias y trabajos comparativos una pieza clave que sirve de bisagra entre los lenguajes que convivían en la Castilla de la primera mitad del siglo XIII².

Recientemente, Jacqueline Jung rescató esta obra en un pequeño artículo en el que aspiraba a "cimentar una base sobre la que otros investigadores puedan construir" ${ }^{3}$, describiendo la portada expuesta en los Claustros, analizando el contenido de las esculturas y proponiendo una explicación para la utilización de los determinados temas iconográficos. El objetivo de este artículo es, por tanto, tomar el testigo de la investigadora americana y deconstruir la portada actual para proponer una nueva forma de construirla desde la historia de la ciudad, de las piezas y de los lenguajes formales y figurativos que en ella confluyen.

\section{A orillas del Ebro}

Al norte de la actual provincia de Burgos, en un extremo de la antigua Castilla la Vieja, al abrigo de los Montes Obarenes, se asienta el valle de Tobalina ${ }^{4}$. Allí, a orillas del Alto Ebro se yergue un promontorio conocido como La Muel, a sobre el cual se dibuja el perfil de la ciudad de Frías, flanqueada a un lado por su castillo almenado y al otro, culminando una curiosa hilera de casas colgantes, el templo parroquial conocido como iglesia de San Vicente (fig. 1).

El edificio que se conserva hoy en día, muestra las cicatrices de sus diversas etapas constructivas, desde los más antiguos arquillos románicos de la iglesia primitiva a las modernas ventanas neogóticas que animan la actual fachada. Al circundar el templo se ponen de manifiesto las consecuencias de las múltiples catástrofes, cuyo recuerdo se aprecia en las numerosas intervenciones. Un arco solitario, único testigo del pórtico del siglo $\mathrm{XVI}$, da paso al flanco sur de la iglesia, donde se distinguen un conjunto de volúmenes dispares correspondientes a las capillas de distintas épocas. En éstas, pequeños vanos de medio punto anuncian un interior oscuro y presentan una clara inadecuación al muro, indicio inequívoco de que fueron colocados allí definitivamente tras sucesivas reformas.

Levantada en el extremo occidental de la Muela, casi al borde del precipicio, la cabecera plana tuvo que ser reforzada con contrafuertes, apoyándose sobre una pequeña sacristía. La irregular disposición del paramento que envuelve los pequeños vanos románicos provenientes de la fábrica más antigua de la iglesia, denuncia las modificaciones que tuvieron lugar en época moderna. El cierre de la nave septentrional también debió de ser renovado, para sustituir a la antigua que se derrumbó en 1879.

Finalmente, la fachada actual es el resultado de una restauración llevada a cabo a principios del siglo XX por el arquitecto José Calleja, culminando de esta manera las incontables reformas del templo. El arquitecto provincial eligió una estructura de tres calles que acompasan a las tres naves del interior de la iglesia, y la coronó con una torre campanario. La puerta de entrada está protegida por un discreto pórtico que, por sus pequeñas dimensiones, ha perdido su utilidad protectora y tan sólo sirve para evocar el pórtico desaparecido5. La diversidad de tipos de piedra utilizados proporciona a la fachada una variada animación, y al no encontrarse más de dos vanos 
iguales, la multitud de formas que combina ventanas ojivales, vanos estrellados y arcos de medio punto, convierten la obra del arquitecto Calleja en un genuino pastiche que poco tiene que ver con la anterior fachada del templo.

En suma, es mucho lo que se ha perdido, pero son las piedras que permanecen las que narran la historia: una historia de crecimiento comercial, de riquezas y construcciones, pero también de incendios, de terremotos y destrucciones. Una historia de una iglesia y una historia de una villa que desde sus inicios corren paralelas en el tiempo, compartiendo avatares y vicisitudes; por esta razón, conocer la historia de la villa es el punto de partida para poder reconstruir la historia de la iglesia.

El historiador del arte Inocencio Cadiñanos Bardeci, gran conocedor de la historia de las Merindades y de los archivos burgaleses, es quien más ha publicado sobre la historia de Frías, culminando con su libro: Frías, Ciudad en Castilla (1999)6. Hay que reconocer su labor de recopilación de fuentes, pues debido al incendio que quemó parte del archivo en el siglo XVI, son muy escasos los documentos medievales que han sobrevivido?. Desde las primeras menciones a viñedos y manzanares, hasta el desarrollo comercial tras la concesión del fuero de Logroño, el historiador describe un proceso que se puede enmarcar de forma muy definida en las políticas regias de control de territorio, como señalaron Iñaki Martín Viso, Ignacio Álvarez Borge o Jose María Monsalvo Antón.

El antes y el después viene marcado por la concesión del Fuero de Logroño en 1202 como parte de un proyecto que llevaría a Alfonso VIII a conceder hasta 19 fueros en esta zona9. El reinado de este monarca se caracterizó por su política de creación de villas para fortalecer el poder regio en aquellos lugares que consideraba más vulnerables, ya fuera por su localización en territorio de frontera o por la concentración de poderes señoriales en la zona. Sin embargo, aunque el objetivo de Alfonso VIII era multiplicar los poderes concejiles para reducir la autoridad de las potencias señoriales afincadas en la región, la proyección territorial de las nuevas villas provocaría múltiples disputas posteriores ${ }^{10}$, como los pleitos que tendrían lugar entre la vecina Oña y Frías durante todo el siglo XIII"1.
Todo apunta a que en 1201, cuando Alfonso VIII compró el "castillo de Frias" de un tal don Armengol, el enclave presentaría un pequeño núcleo poblacional con algún tipo de fortificación y una iglesia primitiva ${ }^{12}$. El edificio de San Vicente actual conserva dos vanos románicos como único vestigio de una posible construcción temprana. Con anterioridad a esta compra tan solo se registran algunas menciones, datando la más antigua del siglo $I X^{13}$.

Con las medidas tomadas por el monarca la villa comenzó a florecer, y con ésta, la iglesia de San Vicente. Al otorgar Alfonso VIII el Fuero de Logroño, estaba concediendo a los futuros habitantes del lugar una serie de ventajas que provocarían un gran movimiento demográfico en la zona ${ }^{14}$. El Fuero de Logroño se caracterizaba por su carácter mercantil y por favorecer los "derechos de francos" 15 . Por un lado, invitaba a los habitantes de los alrededores a trasladarse a la villa, eximiendo de impuestos sobre las casas y heredades que poseyeran fuera de ésta ${ }^{16}$. Se contemplaban, además, privilegios específicos para los habitantes de la Muela -parte alta de la ciudad- concebidos con una intención defensiva ${ }^{17}$. Por otro lado, regulaba la actividad mercantil, lo que sumado a la disposición de 1203 de limitar los mercados semanales de la Bureba a tres, Oña, Pancorbo y Frías, garantizó la supremacía de Frías sobre otras poblaciones de la zona'18. Estos privilegios funcionaron como catalizador para la economía de la villa recién creada; si las menciones documentales anteriores son escasas e imprecisas, a partir del Fuero de Logroño el trazado urbano se va dibujando en el pergamino. La primera mención a la iglesia de Frías se encuentra en un documento de 1211 en el que aparecen además las iglesias de San Vitores, San Juan y de San Pedro' ${ }^{19}$. En 1219 se fundó el Monasterio de Vadillo20, y en 1228 se menciona también un convento de San Francisco ${ }^{21}$.

Probablemente fuera en este primer tercio del siglo XIII, tras la concesión del Fuero, cuando comenzó la principal empresa constructiva de la iglesia parroquial, que parece haber merecido un estatuto más elevado, ya que se constatan por estas fechas tanto la existencia del arciprestazgo de Frías como la figura del arcipreste que ejercería control sobre las restantes iglesias de la villa ${ }^{22}$. Un Diego de Haro, posiblemente perteneciente a la poderosa familia que dominaba la zona riojana, que se documenta en 1211 y 1219 como canó- 


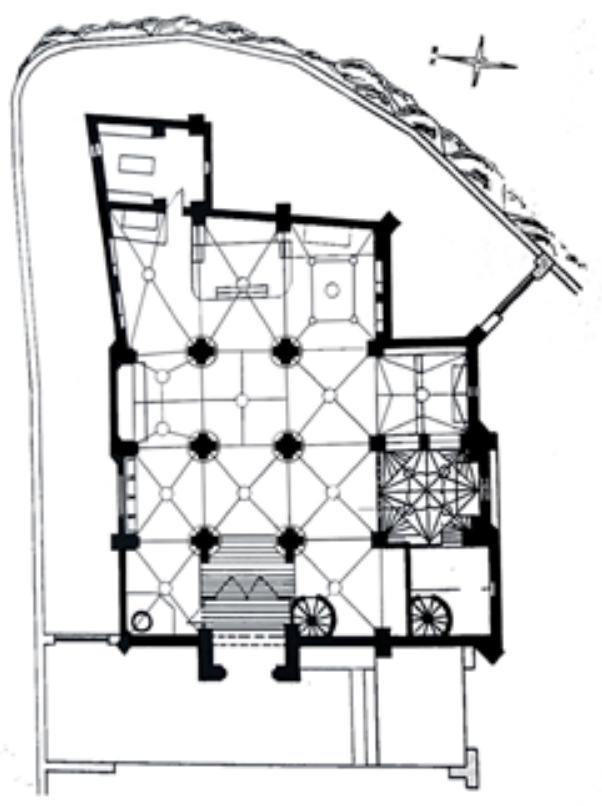

ICLESIA DE SAN VICENTE

Fig. 2. Planta de la Iglesia de San Vicente de Frías (Burgos). Tomada del libro de Inocencio Cadiñanos Bardeci, Frías, Ciudad en Castilla (Frías: Ayuntamiento de Frías, 1999) 107. Modificada con la ayuda de Ignacio Mascuñán Freijanes

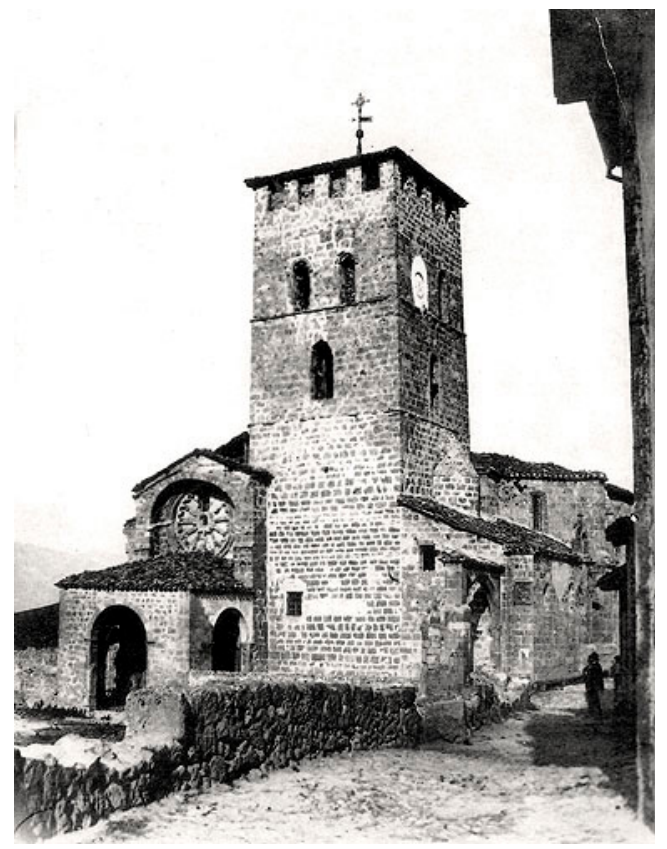

Fig. 3. Iglesia de San Vicente de Frías (Burgos). Anterior a 1906. AMM nigo de Burgos y arcipreste de Frías, hubo de ser uno de los principales responsables de la época de esplendor de la iglesia de San Vicente ${ }^{23}$. No resulta aventurado suponer que en este primer tercio del siglo XIII debió de realizarse buena parte del edificio. A pesar de que las bóvedas actuales de la iglesia han sido modificadas en numerosas ocasiones, los pilares que separan las tres naves, cruciformes con columnas adosadas coronadas por capiteles de decoración vegetal, apoyados sobre plintos cilíndricos, deben de ser originales. Había comenzado a construirse, entonces, un edificio de tres naves con cuatro tramos, que integraría a la pequeña iglesia precedente, con un solo ábside, situada en la zona norte del perímetro del nuevo templo, y se levantarían también los tres ábsides de la cabecera. Hoy pueden verse la capilla mayor dedicada a San Vicente, la capilla de la Concepción, que corona la nave del Evangelio, y la de San Nicolás, que corona la nave de la Epístola. Esta última mantiene su primitiva advocación, porque su altar aparece documentado ya en $1230^{24}$ (fig. 2).

Un segundo arcipreste que contribuyó de modo importante a la fábrica, fue un don Fernando, que en 1280 funda una capellanía para que se cantase siempre por su alma, y dona ciento sesenta maravedíes para la obra de San Vicente, que se sumarían a los que dice haber ofrecido anteriormente "...quando se començo la obra..." 25 . De lo que parece una manda testamentaria del arcipreste, cabe deducir que hacia 1280 la obra de la iglesia estaba ya muy avanzada, dado que la fachada occidental debía ya de estar en pie. A pesar de que la que se observa hoy día es el fruto de una reconstrucción posterior, como se verá, es posible aproximarse a su apariencia original gracias a una antigua fotografía y a la descripción que del templo proporciona el Padre Quintana en $1887^{26}$. Estaría decorada con las esculturas que se conservan ahora en el Museo de los Claustros, y se remataría con un rosetón sencillo con un óculo central del cual parten doce radios. Por la fotografía se pueden inferir la presencia de unos capiteles en los extremos de los radios, de modo que el gran vano evocaría estructuras como las de San Pedro de Ávila, o Santo Domingo de Soria. La fotografía mencionada no permite conjeturar una fecha para la edificación de la torre, pero el montante de la contribución de don Fernando en 
1280 podría corresponderse con su construcción a finales del siglo XIII (fig. 3).

Excede los límites de este trabajo extenderse sobre la historia del edificio, para lo cual me remito de nuevo al texto de Inocencio Cadiñanos, el cual recoge las principales modificaciones y fundaciones de la fábrica, destacando especialmente la capilla del Santísimo Cristo de las Tentaciones y la de la Visitación ${ }^{27}$. A partir de 1605, fecha tomada de una inscripción que conmemora la reparación de la Torre, los libros de fábrica comienzan a mostrar un historial de grietas y reparaciones que conducen de forma inexorable a los desastres del siglo XIX. Primer derrumbe del pórtico en $1836^{28}$, hundimiento del baptisterio en 187929, y el incendio de $1897^{30}$.

Ante el lamentable estado en que se encontraba la iglesia, en junio de 1906 se hizo un llamamiento al arquitecto provincial para que se acercase a reconocer el edificio y proyectase las reparaciones pertinentes. Por entonces, la iglesia sufría importantes problemas de estabilidad, debidos al excesivo peso de la torre $y$, al verse privada de una de las naves, la ruina era inminente. Por ello, el 14 de noviembre tuvo lugar "el hundimiento de la torre del templo parroquial de San Vicente de Frías que afortunadamente no ha ocasionado desgracias personales pero si materiales de consideración en los tejados y bóvedas de la iglesia" 31 (fig. 4).

La torre se había llevado toda la fachada por delante, incluyendo el rosetón gótico y la portada esculpida. A raíz de esta desgracia, entre los años 1906 y 1916, el arquitecto provincial José Calleja viajó regularmente a Frías para supervisar las labores de reparación de la iglesia que él había diseñado, siguiendo las pautas del "neohistoricismo" ${ }^{2}$. Sin embargo, en algún momento entre la caída de la torre y 1923, parte de las piezas que habían sobrevivido pudieron ser recuperadas y vendidas para aparecer, sorprendentemente, al otro lado del océano, en el Museo Metropolitano de Nueva York.

La historia de la traslación de las piezas desde la península hasta Manhattan hunde sus raíces en la tradición oral, pues no se conservan documentos de venta que permitan desentrañar el proceso de enajenación de la portada de Frías ${ }^{33}$. Ante el silencio de las pruebas, tan sólo se pue-

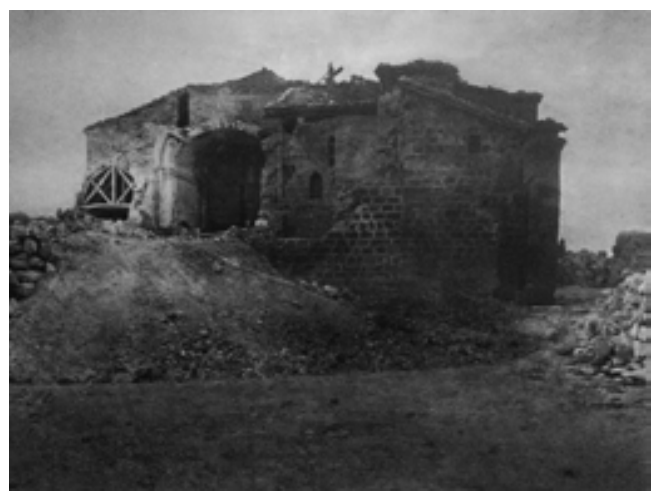

Fig. 4. Iglesia de San Vicente de Frías (Burgos). Tras la caída de la torre en 1906. Ayuntamiento de Frías

den exponer los datos e informes que se conocen y especular sobre el posible viaje de las piedras en una historia de misterio, piedras torturadas, ventas ilegales y magnates multimillonarios.

Cuando la torre de San Vicente de Frías se cayó en 1906, dejó a los habitantes de la ciudad con un gran trabajo de desescombro y sin dinero para costear la reparación de la iglesia. A la espera de una solución, los restos de la portada fueron apilados detrás del templo, donde parece ser que estuvieron sufriendo a la intemperie hasta que don Luciano Huidobro donó un dinero para que se protegieran con unas tejas ${ }^{34}$. Este testimonio concuerda con la descripción que se conserva de 1923, cuando un vocal de la Comisión Provincial de Monumentos de Burgos hizo saber que en la ciudad de Frías había habido "una portada románica de algun interes arqueologico, y que al hacer el descombro, los restos un tanto mutilados de tal portada se apilaron al aire libre, donde han estado sufriendo las inclemencias del tiempo" ${ }^{35}$.

En un momento que se desconoce, las piezas de la portada fueron vendidas y abandonaron la ciudad. Aunque no se conserven documentos escritos al respecto, es posible que la Historia de Frías, publicada en 1944 por Agustín Villasante, contase con testimonios orales que aún recordaran los hechos. De acuerdo con este autor, para poder costearse la reconstrucción de la iglesia, fue necesario enajenar algunas de sus propiedades. Por ello, se transportaron en secreto las piezas de la portada, que se vendieron por 15.000 pesetas. Para ello hizo falta la colaboración del 


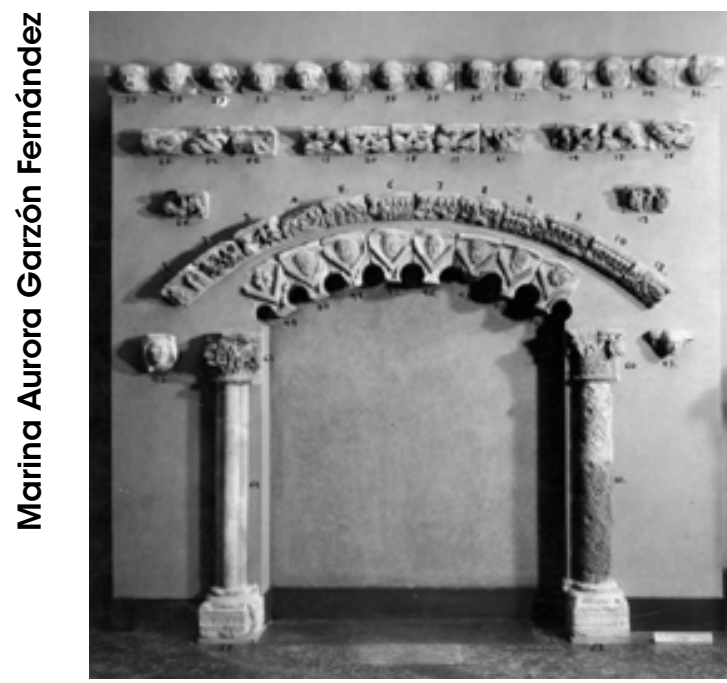

Fig. 5. Portal de San Vicente de Frías (Burgos) expuesto en el Museo Metropolitano de Nueva York (1924) AMM

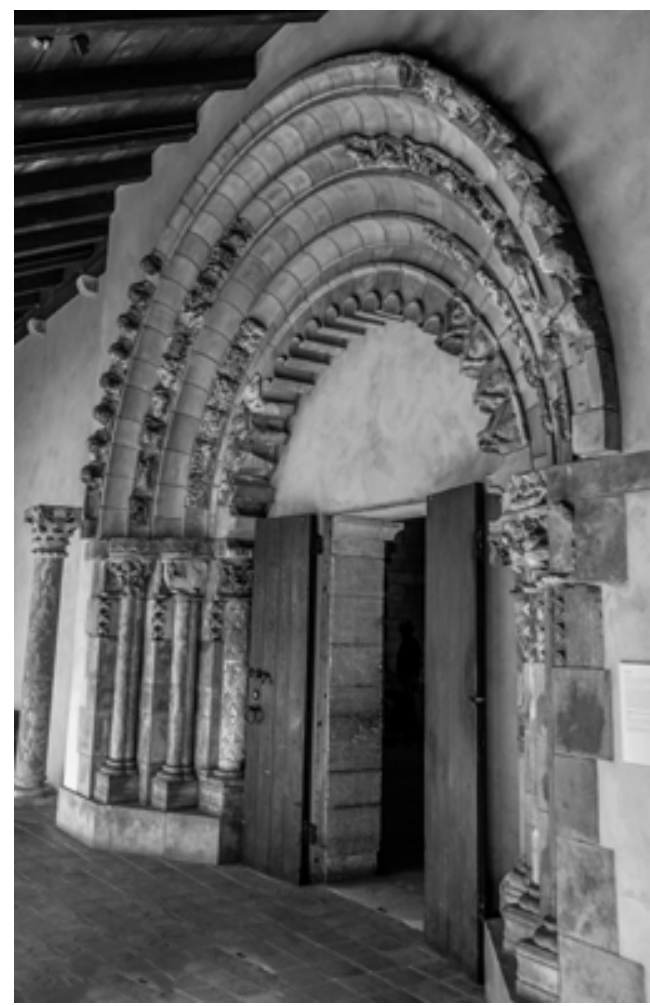

Fig. 6. Portal de San Vicente de Frías (Burgos) expuesto en el museo de Los Claustros de Nueva York párroco, Vicente Montoya, y del Cardenal Juan Benlloch y Vivó, arzobispo de Burgos ${ }^{36}$.

En 1923, comenzaron a correr rumores por la zona de Burgos sobre unas ventas ilegales que habían tenido lugar en las localidades de Frías, Boadiella y Sasamón ${ }^{37}$. Esto puso a la Comisión Provincial de Monumentos de Burgos sobre aviso e inició una investigación para contrastar la veracidad de estas afirmaciones ${ }^{38}$. Mientras los delegados de la Comisión se entrevistaban con el párroco de Frías que afirmaba que se habían vendido unas "...piedras abandonadas, de escaso valor arqueológico apreciable" ${ }^{39}$, las piezas llegaban por mar a Manhattan, donde se pueden situar con seguridad en el sótano del galerista Joseph Brummer en marzo de $1923^{40}$.

Christine Brennan ha estudiado las actividades de este galerista y cuenta como el coleccionista Henry Walters adquirió estas piezas en 1923, que acto seguido serían vendidas al Museo Metropolitano por la suma de 50.000 dólares ${ }^{41}$.

Una vez en el Museo Metropolitano, las piezas fueron expuestas por primera vez en 1924 con ocasión de la reorganización de las salas de Arte Medieval y Renacentista, en las que se presentaron las nuevas adquisiciones, entre ellas, las esculturas de Frías, que fueron descritas por el conservador del museo Joseph Breck como "...la exhibición más llamativa de la sala" 42 . Al carecer de la información necesaria sobre la apariencia original de la portada de Frías, ordenaron los relieves de acuerdo a su temática y morfología, como se puede apreciar en una fotografía de este primer montaje. La disposición de las piezas evoca en cierto modo un arco del triunfo romano, formato habitual en las portadas románicas peninsulares del siglo XII (fig. 5).

Tras haberse exhibido en el Museo Metropolitano de Nueva York, el conjunto de las piezas fue cedido en 1932 al Museo de Los Claustros, que había comenzado a diseñarse en 1931 con el propósito de albergar la colección de arte medieval del Museo Metropolitano, así como los restos conservados de cinco claustros románicos que habían pertenecido anteriormente al escultor George Barnard43 (fig. 6).

Para realizar el nuevo montaje, los técnicos del museo se basaron en la descripción del Padre Ce- 

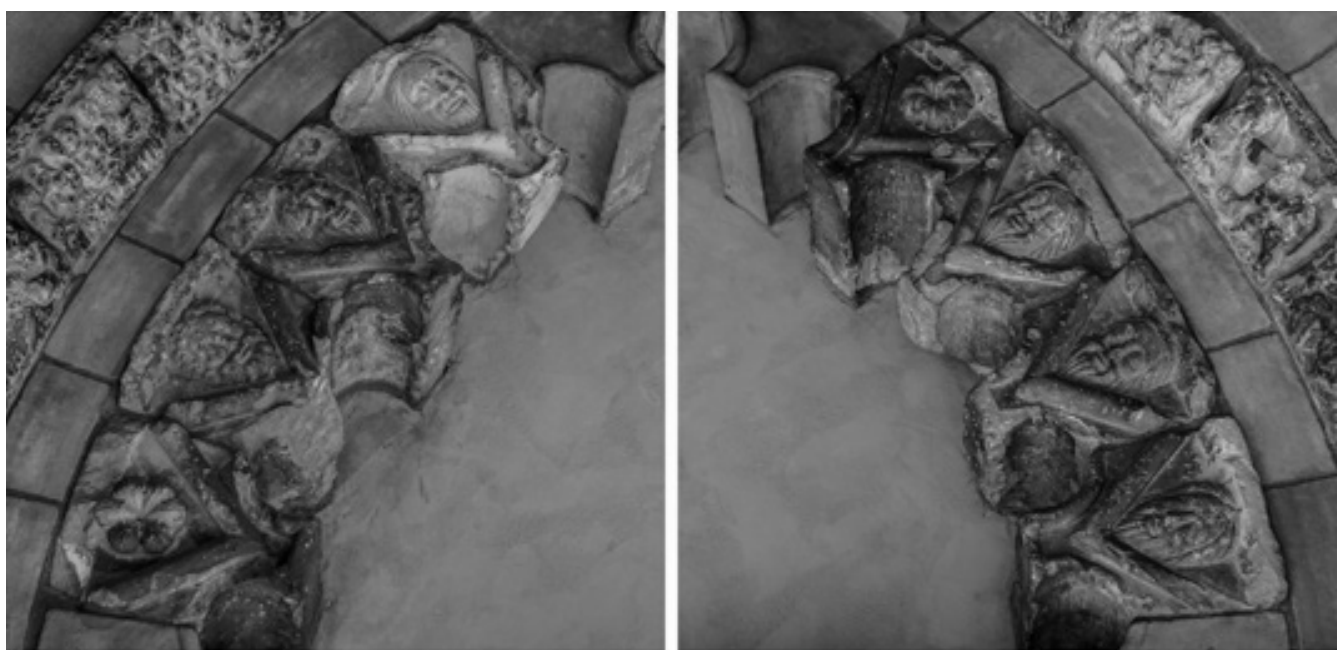

Fig. 7. Dovelas interiores. Portal de San Vicente de Frías (Burgos). Los Claustros. Nueva York

lestino Quintana y en la comparación con otras portadas románicas de la época ${ }^{44}$. Siguiendo las indicaciones del texto, los conservadores dispusieron las piezas conservadas en cuatro arquivoltas. Tomando la arquivolta interior como medida, asentaron las piezas restantes sobre este formato, siguiento criterios iconográficos y estilíisticos ${ }^{45}$. Esta reconstrucción, que se puede admirar hoy en día, es la misma que vieron los primeros visitantes del museo cuando abrió sus puertas por primera vez en $1938^{46}$.

\section{A orillas del Hudson}

El montaje de la portada en el Museo de los Claustros confirió un lugar central a las esculturas llegadas de la periferia burgalesa. Sin embargo, el paso del tiempo y la distancia casi las relegarían al olvido. Aunque Joseph Breck prometía en 1923 una entrada en el Boletín del Museo con un estudio pormenorizado, el artículo nunca llegó, y poco a poco las llamativas esculturas fueron perdiendo importancia en favor de otras piezas más mediáticas ${ }^{47}$.

Pero la portada de Frías no es sólo una portada olvidada, es una portada perdida. Resulta imposible saber cuántas piezas faltan de la obra original, cuántas fueron destruidas al caer la torre ni cuántos fragmentos no fueron adquiridos por el marchante. El estado de la portada descrito por el Padre Quintana antes de la caída de la torre ya resultaba desolador, con múltiples esculturas carcomidas por el paso del tiempo y mancilladas por la irrespetuosa mano del hombre ${ }^{48}$. Ante esta situación, el investigador se encuentra con un puzzle al que le falta un número indeterminado de piezas. Además, -continuando con la metáfora lúdica- los montajes de 1924 y 1938 juegan a favor o en contra, pues se presentan como posibilidades que no pueden ser confirmadas ni desmentidas. Estos montajes contribuyen a nublar la percepción del espectador, ofreciendo soluciones comparables a una portada de tipo arco-triunfal -1924- o al esquema típico de arquivoltas de medio punto paralelas del tardorrománico burgalés-1938; afincando en el receptor la idea de que la portada de Frías responde al mismo esquema que portadas como las de Moradillo de Sedano o Cerezo de Riotirón ${ }^{49}$. Sin embargo, si el investigador se acerca a las piezas con los ojos vendados, tratando de olvidar montajes anteriores, se evidencia que las posibilidades no están agotadas.

La información más importante sobre el formato de la portada lo proporcionan las piezas de la arquivolta interior. Sobreviven ocho dovelas con forma de hoja de hacha, perfiladas con baquetilla y con una gruesa moldura en forma de $\checkmark$ que cobijan sendas rosetas o rostros barbados, conformando una arquivolta interior polilobulada (fig. 7). María Moreno Alcalde que estudió la simbología de las portadas polilobuladas, cita una serie de ejemplos de finales del XII y principios del XIII que pueden servir de paralelos para 

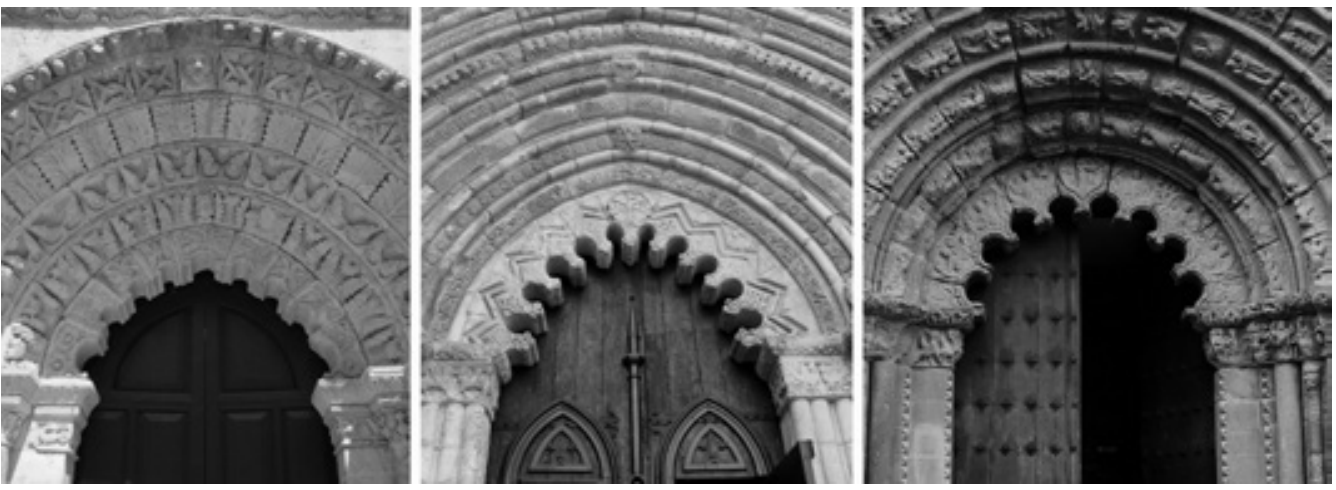

Fig. 8. Iglesia de la Magdalena (Zamora). Iglesia de Santiago de Puente la Reina (Navarra). Iglesia de San Pedro de la Rúa (Navarra)

el caso fredense, y plantean formas alternativas de pensar la portada, como son los casos de la Magdalena de Zamora o las tres iglesias hermanas de Santiago de Puente la Reina, San Pedro de la Rúa en Estella o San Román de Cirauqui en Navarra50 (fig. 8).

La disposición escogida por los técnicos del Museo Metropolitano, obtenida al dibujar un arco de medio punto manteniendo la curvatura natural de las piezas, dio lugar a un vano de luz colosal en el que no terminan de adaptarse unas dovelas relativamente pequeñas ${ }^{51}$. En mi opinión, se debería barajar la opción de un arco ligeramente apuntado, como en la Magdalena de Zamora, y no desentonaría con versiones locales de portadas historiadas, como Vallejo de Mena o San Andrés de Soto de la Bureba ${ }^{52}$.

Proponer un formato alternativo, como es una portada de arquivoltas apuntadas, para las piezas conservadas de Frías, requiere que las esculturas sean consistentes con este planteamiento y puedan adaptarse a él morfológica y estilísticamente. Hasta el momento, la portada de San Vicente de Frías ha sido analizada por los estudiosos, no sin razón, como un ejemplo paradigmático del tardorrománico burgalés, basándose principalmente en paralelos iconográficos y en la supuesta vinculación de la escultura con el mecenazgo de Alfonso VIII53. Efectivamente, en una primera aproximación a los fragmentos conservados, las piezas más llamativas destacan por su ascendencia silense: los capiteles responden a modelos ampliamente difundidos por la península a lo largo de todo el siglo XII, y el ciclo cristológico localizado ahora en la segunda arquivolta remite a los múltiples ciclos cristológicos esparcidos por los claustros de Castilla y Navarra.

Sin embargo, un análisis más pormenorizado de las esculturas delata una serie de tratamientos formales que sólo pueden ser explicados a través de un diálogo entre escultores formados en la tradición tardorrománica silense, con las nuevas propuestas desarrolladas en la fábrica de la catedral de Burgos. Ante la dificultad que supone identificar con claridad talleres o manos en el equipo de trabajo de cualquier portada medieval, tomaré prestados de Esther Lozano y Daniel Rico Camps los términos de modo y temperamento para intentar aproximarme a las características estilísticas que se pueden discernir en las esculturas de Frías ${ }^{54}$. Por un lado, están las piezas de "temperamento narrativo", que destacan por la habilidad para contar historias a través de la acumulación de personajes de ojos almendrados y cabeza redondeada, y, por otro lado, los escultores de "temperamento decorativo" que optaron por seleccionar sujetos aislados en los que prodigarse con los detalles y las texturas ${ }^{55}$. Aunque se trata de temperamentos bien diferenciados y fáciles de identificar, ambos conjugan a su manera la tradición silense y la tradición gótica burgalesa. Además, el conjunto escultórico no es homogéneo en las calidades de la talla, y se pueden distinguir modos de hacer en función de la mayor o menor destreza de los artífices.

El ciclo cristológico, con su aglomeración de figuras isocefálicas, evoca una tradición figurativa con un sofisticado modo narrativo que saltó de las pandas occidental y meridional del claustro de Silos para evolucionar y extenderse a través de 

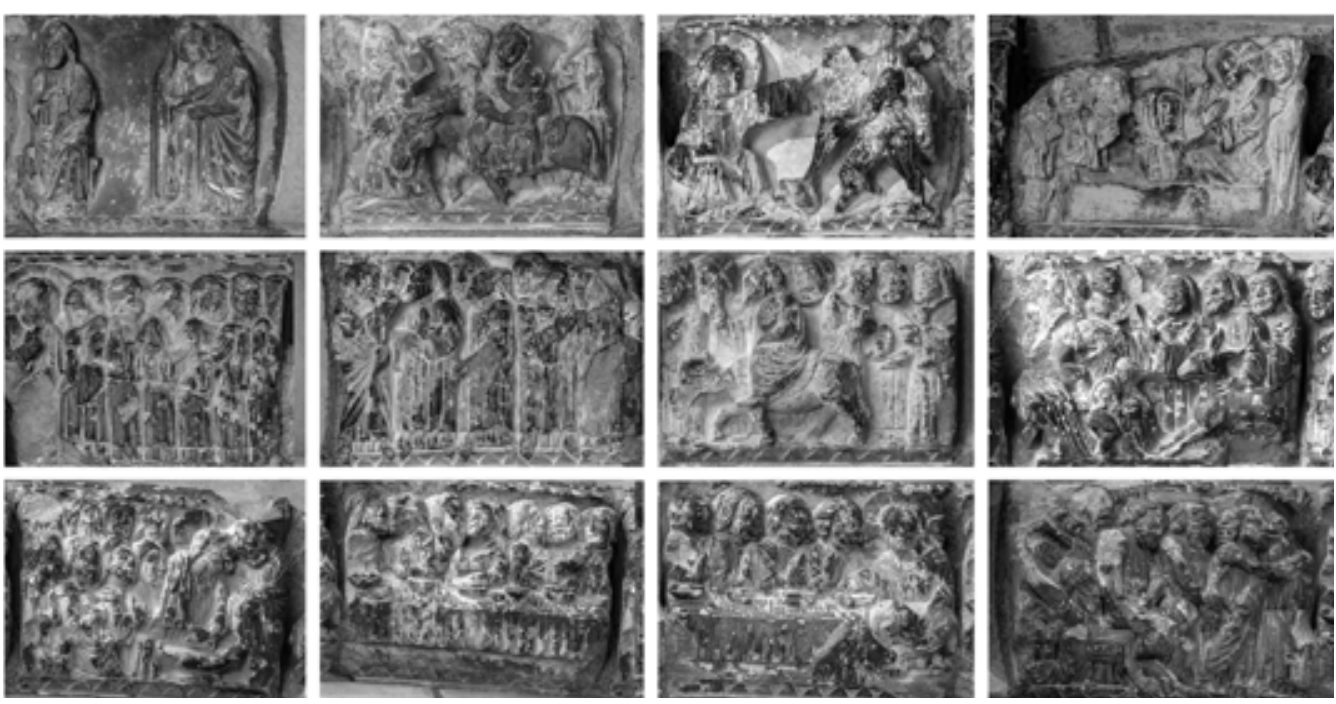

Fig. 9. Escenas de la vida de Cristo. Portal de San Vicente de Frías (Burgos). Los Claustros. Nueva York

múltiples intercambios por las iglesias del reino de Castilla, destacando como focos importantes Burgo de Osma y Santo Domingo de Soria. Sin embargo, aunque el éxito de la solución soriana se vería reflejada en las múltiples reinterpretaciones, entre las que cabe destacar Moradillo de Sedano, las tallas de Frías no parecen encajar del todo estilísticamente entre las iglesias derivadas del segundo taller de Silos, que Charlotte de Charette recoge en su tesis ${ }^{56}$. El tratamiento del espacio en las dovelas fredenses, donde los personajes necesitan aglutinarse y superponerse, parece estar más vinculado a un sistema narrativo más propio de capiteles que de arquivoltas de tradición soriana, en las que a cada personaje se le hace corresponder con un espacio propio (fig. 9).

La mayoría de las piezas conservadas denotan este "temperamento narrativo", desde las dovelas lobuladas de la arquivolta interior a las que componen los ciclos más importantes como el ciclo cristológico, el ciclo de la vida de San Millán o las representaciones de los vicios, instalados hoy en la tercera arquivolta57. Parece claro que los escultores estaban interesados en explorar y explotar todos los recursos a su disposición, pues no solo jugaron con el espacio narrativo, sino que reinterpretaron, a su manera, y con sus característicos ojos almendrados, marcados pómulos y mentón retraído, los frisos de cabezas flotantes que decoran el triforio de la catedral burgalesa (ca. 1240) ${ }^{58}$. Asimismo, las figuras realizadas con más destreza, como el José situado contiguo a la Visitación ${ }^{59}$, caracterizado por su canon más alargado, el suave modelado del rostro, la rica notación del cabello y los pliegues acartonados, evocan fórmulas que permiten relacionarlo con modelos presentes en los frisos de los tímpanos de las Portadas del Sarmental o de la Coronería de la catedral de Burgos ${ }^{60}$.

El influjo catedralicio que se deja sentir en las esculturas fredenses puede hermanarse con otros ciclos escultóricos pertenecientes también a la familia de derivados del Sarmental, como pueden ser un grupo de sarcófagos palentinos provenientes de monasterios de la zona de Carrión de los Condes. Aunque la escultura de estos sepulcros, conservados en el Museo Arqueológico Nacional o en San Pedro de Cisneros (Palencia), no encuentra relación directa con la portada de Frías, ofrece un paralelismo al ejemplificar el proceso de adaptación de una gran portada gótica a escultura de pequeño formato, como la del lateral de un sarcófago. La simplificación de los pliegues en zig-zag, trasunto de la corriente del gótico conocida como "cubista", da lugar a unas telas acartonadas que se repetirán en el José de Frías, o en la Deesis del arca sepulcral del Museo Arqueológico Nacional'¹. 


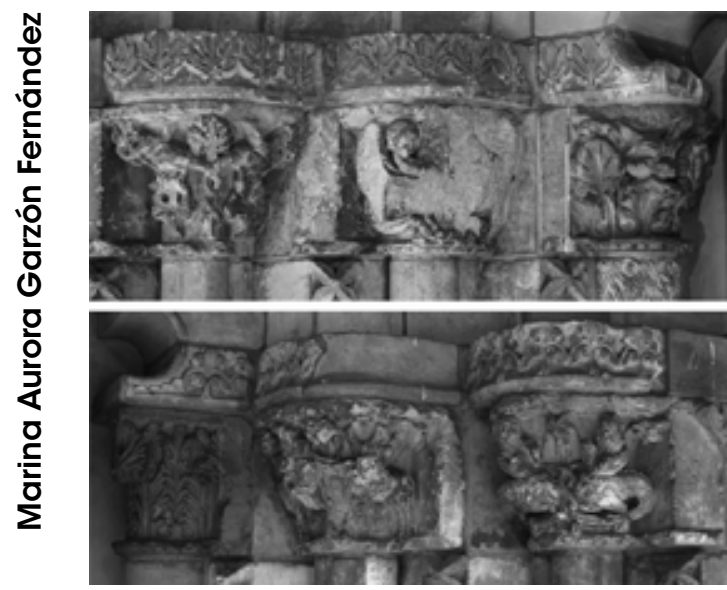

Fig. 10. Capiteles del Portal de San Vicente de Frías (Burgos). Los Claustros. Nueva York
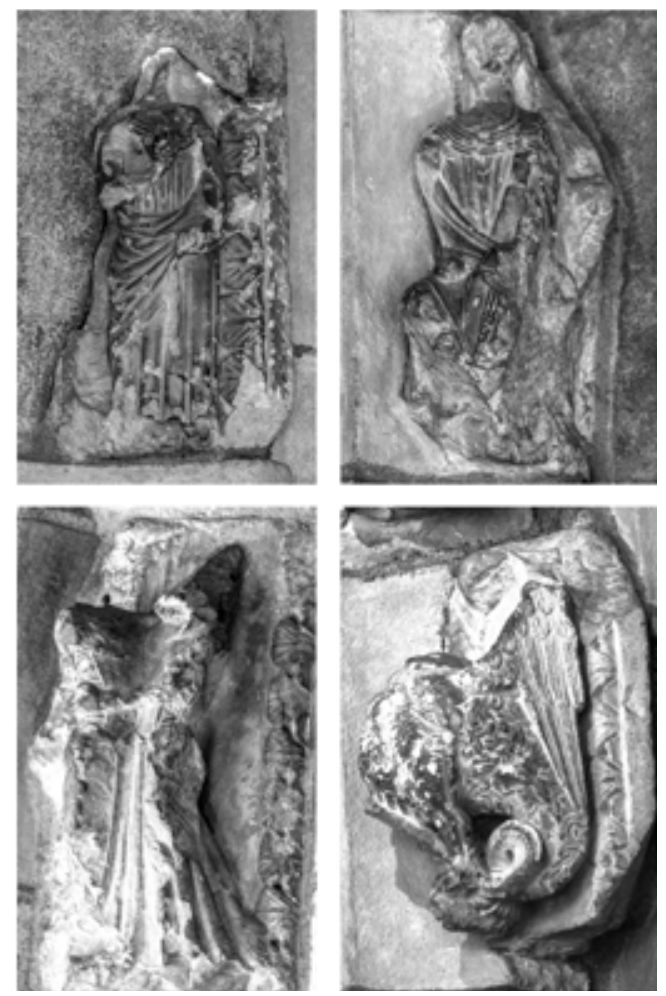

Fig. 11. Hombre. Músico. Lucha de púgiles. Arpía. Portal de San Vicente de Frías (Burgos). Los Claustros. Nueva York
Frente a los escultores de inquietud narrativa, sus compañeros, con una sensibilidad más decorativa, parecen recrearse en el ejercicio opuesto: construir pequeñas figuras monumentales como se puede apreciar en la serie de seis capiteles que coronan las columnas del derrame abocinado de la portada ${ }^{62}$ (fig. 10). Cada pieza tiene su paralelo en portadas clásicas del tardorrománico derivado de Silos, como en Cerezo de Riotirón, Moradillo de Sedano o Soto de Bureba; sin embargo, estos escultores optaron por tomar los tópicos iconográficos del acanto, los caballeros, las arpías o los seres híbridos y vestirlos de galas góticas importadas de la gran ciudad ${ }^{63}$.

Las hojas suculentas de nervios perfilados y profundos trepanados que florecen en los capiteles de San Vicente y se extienden hasta los cimacios con hojas de talla carnosa y fuertes contrastes de luces y sombras, apenas se distinguen de algunos motivos presentes en las claves de bóveda del deambulatorio de la catedral de Burgos o en los capiteles del Sarmental (ca. 1230)64.

La delicadeza de líneas se repite en varias esculturas de la portada de Frías, hoy dispuestas en la tercera arquivolta -específicamente las dovelas con tallas verticales como el músico o el hombre sosteniendo la presilla del manto-, además de un ángel de gran formato conservado en los fondos del museo ${ }^{65}$. El tratamiento de estas figuras se aleja de los personajes del ciclo cristológico, de pliegues aplanados y redondeados frente a la seguridad cortante y afilada que se percibe en las líneas del hombre con espada o del ángel. Esta nitidez en la talla y el juego plástico de estos escultores alcanza su máximo exponente en las dovelas del buey y el cérvido de la tercera arquivolta, donde el detallismo anatómico insufla vida a estos animales que casi parecen respirar (Figs. 11 y 12).

En conjunto, la fragmentaria obra de San Vicente trasluce una convivencia entre dos lenguajes formales que podría explicarse, no tanto por escultores que trabajaran en la fábrica de Burgos y luego fueran a Frías, sino por artífices con una profunda formación en la tradición local, que decidieron experimentar a su manera con las nuevas aportaciones que se estaban llevando a cabo en la catedral castellana. 
Esta combinación entre lenguaje tradicional y nuevas tendencias es lo que ha derivado en confusión a la hora de analizar esta portada. Precisamente aquellas piezas de iconografía más conservadora, como el ciclo cristológico y los monstruos de los capiteles, son las que han llevado a adelantar la fecha de composición de la portada al primer tercio del siglo XIII, correspondiéndose con las últimas experiencias del tardorrománico ${ }^{66}$. Sin embargo, la presencia de escultores provenientes de la Catedral de Burgos obliga a retrasar esta fecha ${ }^{67}$. La llegada de estos talleres a la villa de Frías podría vincularse al arcipreste Diego de Haro, antiguo canónigo de la catedral de Burgos ${ }^{68}$. Es esta relación con las canteras de la sede catedralicia, el conocimiento de soluciones como las decoraciones vegetales datadas hacia 1230 o los frisos de cabezas del triforio desarrollados hacia 1240, la que proporciona un posible término post quem que invita a situar la elaboración de la portada de Frías a mediados del siglo XIII, cuando, como demostraba la documentación, la iglesia debía de estar ya casi terminada. Estas fechas, alejadas del hipotético patrocinio regio de Alfonso VIII antes mencionado, coincidirían, por otro lado, con la época de plena expansión de la villa, caracterizada por el crecimiento comercial y económico, ambiente idóneo para que confluyeran en Frías estos escultores.

Aunque la pérdida de una porción incalculable de las piezas y la imposibilidad de conocer la disposición original dificulta el estudio del programa iconográfico, se pueden reconocer algunos temas que destacan con claridad y que encajan en el contexto de una villa comercial de promoción regia. Dado que la extensión de este trabajo me impide describir con detenimiento el centenar de piezas conservadas, me limitaré a esbozar los principales ciclos y mensajes que he podido desentrañar en el estudio de estas piezas ${ }^{69}$.

En primer lugar, el ciclo más destacado por su extensión es, sin duda, el formado por las doce dovelas de temática cristológica: la Visitación, la Huida a Egipto, Tentación de Cristo en el desierto, la Resurrección de la hija de Jairo, la Vocación de los Apóstoles, la Curación del Mudo, la Entrada en Jerusalén -desarrollada en dos dovelas-, el Lavatorio, la Última Cena -también extendida en dos dovelas- y el Prendimiento (fig. 9). No
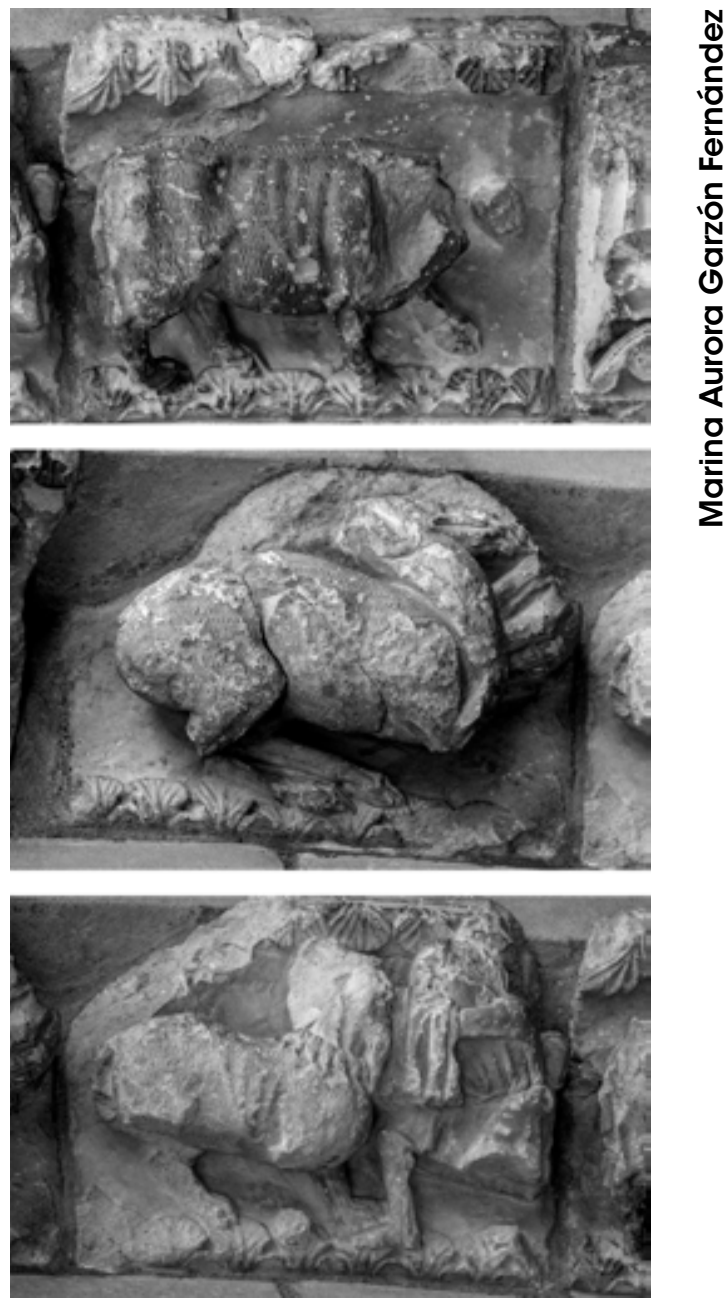

Fig. 12. Buey. Ciervo. Lucha con híbrido. Portal de San Vicente de Frías (Burgos). Los Claustros. Nueva York

parece aventurado suponer que se hayan perdido algunas escenas bastante habituales, como la Natividad o una Crucifixión que culminara el ciclo de la Pasión, pero aún así no deja de llamar la atención, como ya señaló Jacqueline Jung, el gran énfasis en la vida pública de Cristo $^{70}$. Sin embargo, al pensar en la audiencia de estas imágenes, es decir, los habitantes de Frías, resulta fácil imaginarlos reflejados en los testigos que presencian los milagros realizados por el Mesías. En cierta forma, la gran cantidad de personajes que incluye este ciclo podría evocar el bullicio que debió caracterizar a la ciudad del Ebro, donde sin 


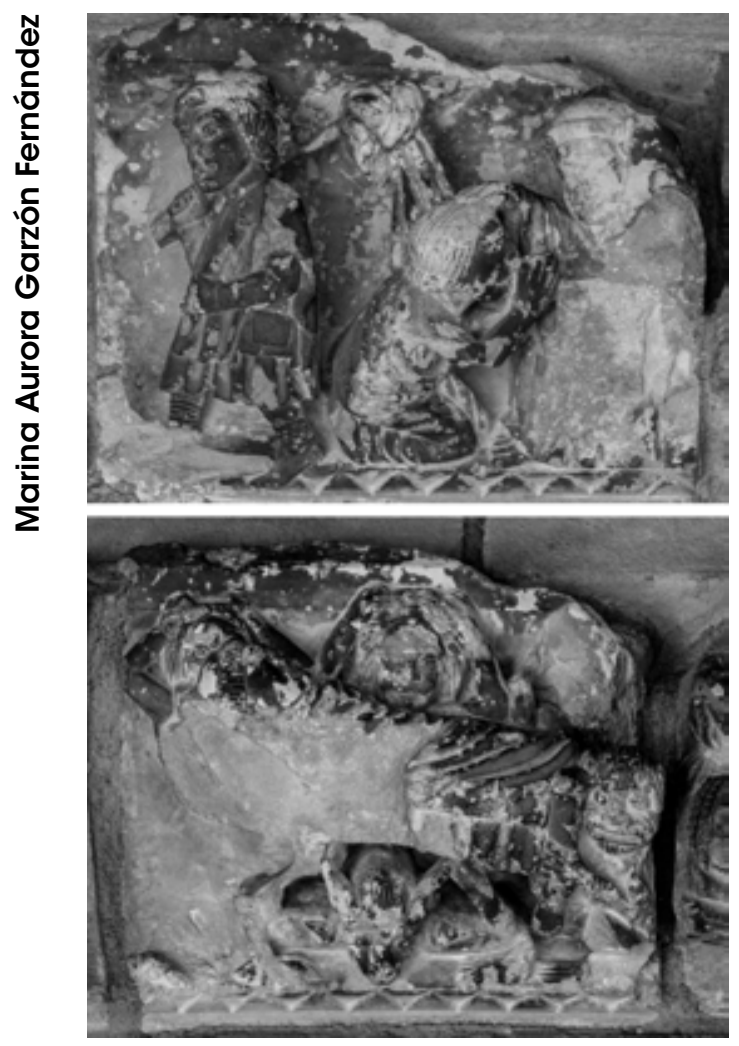

Fig. 13. Escenas de la vida de San Millán. Portal de San Vicente de Frías (Burgos). Los Claustros. Nueva York

duda no faltaría quien anhelase experimentar un milagro.

El interés por los milagros se hace patente también en dos dovelas donde creo posible identificar escenas de la vida de San Millán, las piezas que James Rorimer describió en el catálogo del Museo de los Claustros como "un monje bendiciendo a un hombre que comienza un viaje" y "el monje en su lecho de muerte"71 (fig. 13). En efecto, la primera dovela representaría la Instrucción de San Millán, en la que se aprecia, tal y como narró su hagiógrafo el obispo Braulio de Zaragoza en el siglo VI , a San Millán arrodillado delante de San Felices de Bilibio, su maestro, que le bendice antes de emprender el camino de vuelta a las tierras riojanas a las que se retiraría para llevar una vida eremítica72. Dada la escasez de ciclos de San Millán, conservados resulta difícil establecer paralelismos iconográficos entre ellos, sin embargo, la relación entre el santo de la Rioja y su maestro,
San Felices de Bilibio, aparece plasmada tanto en la arqueta de marfil del siglo XI-que en tiempos guardó las reliquias del santo y ahora se conserva en el monasterio de San Millán en Yuso-, como en los frescos del siglo XIII de la iglesia segoviana de San Millán, y en el altar policromado del siglo XIV custodiado en el Museo de Logroño y conocido como Tablas de San Millán ${ }^{73}$.

En cualquier caso, la escena de un monje en actitud de ser bendecido resulta insuficiente para reconocer un ciclo hagiográfico, y se hace necesaria la presencia de algún milagro que pueda concretar la identidad del santo. En este caso, el relieve de la portada de Frías que revela una extraña escena de alcoba, en la que unos diablos monstruosos levantan la cama de un hombre ante la mirada sorprendida de unos personajes que se llevan las manos a la cabeza, podría aludir al episodio conocido como el Concilio de los Demonios $^{74}$.

Braulio de Zaragoza contaba cómo los energúmenos endemoniados a los que intentaba ayudar San Millán se lo agradecían tratando de incendiar su cama con teas candentes. Este episodio sufrió una curiosa transformación textual e iconográfica a lo largo del tiempo. La humanidad de estos seres desgraciados, que aparecen representados en la arqueta de San Millán como hombres con antorchas y en el cenotafio pétreo de San Millán (ca. 1200) como tenantes barbados que sostienen la tumba del santo, se vería desbancada por su faceta de seres endemoniados ${ }^{75}$. En el siglo XIII, el texto de Braulio sobre San Millán sería revisado y en el propio monasterio emilianense se elaborarían dos nuevas versiones con la intención de reavivar el culto al santo. Por un lado, el monje Fernando escribió el Liber Miraculorum en el primer cuarto del siglo XIII, que serviría como base a Gonzalo de Berceo para elaborar su Vida de San Millán de la Cogolla, escrito en lengua vernácula ${ }^{76}$. Éste último amplificaría el episodio de los energúmenos, convirtiéndolo en un entretenido diálogo entre diablos. El escritor, que había tenido acceso tanto a la arqueta de marfil de Yuso (s. XI) como al cenotafio de Suso (s. XIII), reelaboró la historia tomando como protagonistas a cada uno de los diablos que se habían enfrentado previamente al ermitaño, y describió una conspiración para incinerarlo ${ }^{77}$. 

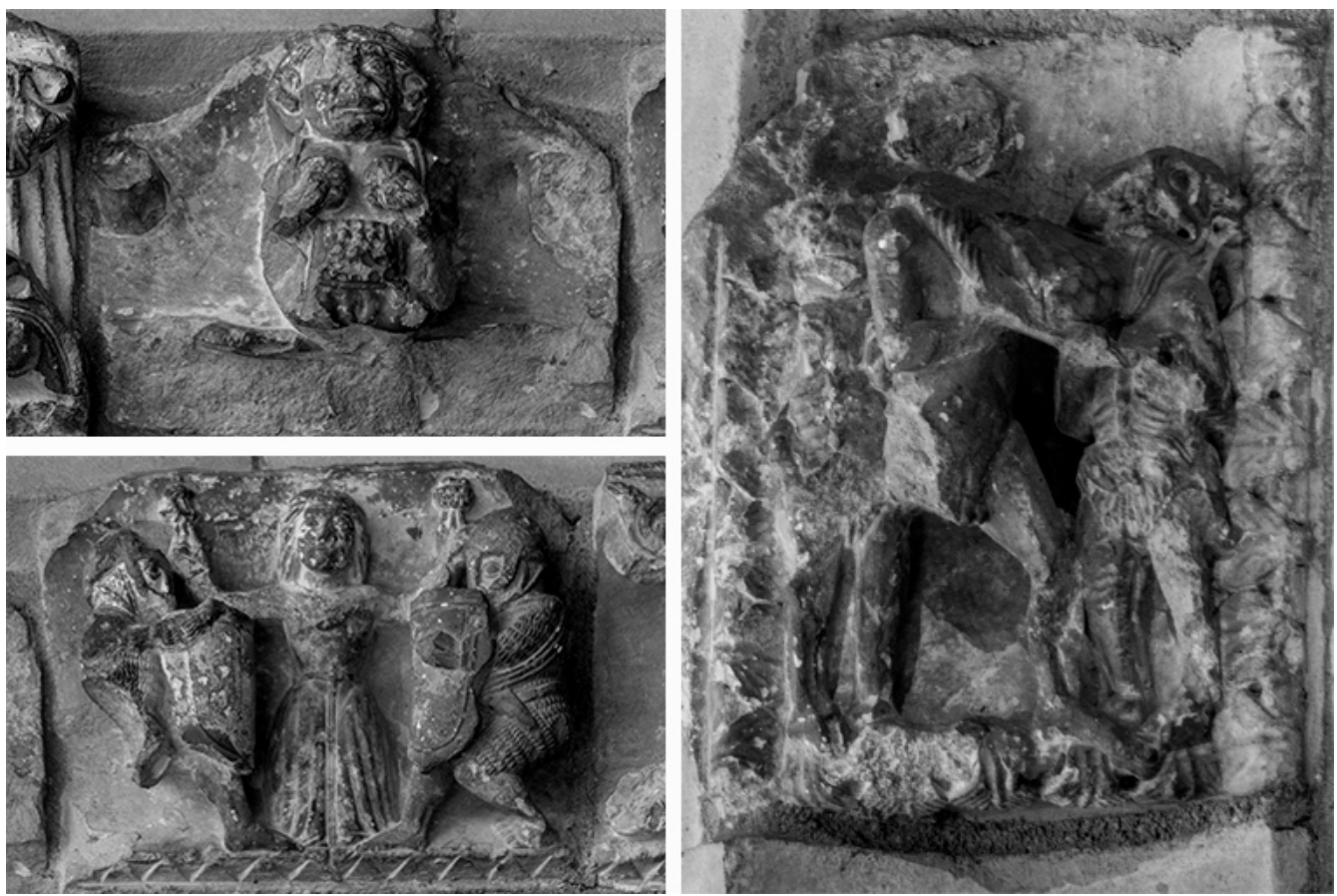

Fig. 14. Avaro. Tregua domini. Avaro. Portal de San Vicente de Frías (Burgos). Los Claustros. Nueva York

En la dovela de la portada de Frías se recreó este episodio. El santo recostado en su lecho ocupa la parte central, y a sus pies, un energúmeno barbado se aferra a una de las patas mientras un diablo cornudo levanta la cama con sus garras ${ }^{78}$. En segundo plano, unas figuras muy deterioradas parecen llevarse las manos a la cabeza en señal de perplejidad. En Frías, como en Berceo, los energúmenos se han convertido en diablo, como lo harán después en las tablas de San Millán del Museo de Logroño (s. XIV), en las que un conjunto de demonios armados con antorchas encendidas se atacan unos a otros ante la mirada sorprendida del ermitaño yacente. La presencia de este episodio en los principales ejemplos figurativos basados en la hagiografía de San Millán confirman la importancia de este pasaje como uno de los más representativos.

La sorprendente intrusión del ciclo de San Millán en la portada burgalesa podría explicarse en relación con el conocido como "voto de San Millán", un impuesto que el cenobio riojano exigía al territorio castellano por haber auxiliado supuestamente a Fernán González en la batalla de Hacinas ${ }^{79}$. El documento falso, que enumera las localidades que contribuían al Voto, curiosamente menciona al alfoz de Petralada, en el que se encuentra Frías ${ }^{80}$. La nueva villa no sólo pagaba cuota al monasterio, como hacían muchas poblaciones castellanas, sino que parece haber tenido cierto contacto con la región riojana, a través de familias importantes como la del arcipreste Diego de Haro, y además, el monasterio de San Millán tenía posesiones en la región del Tobalina ${ }^{81}$. El santo es mencionado, adicionalmente, en el testamento de Fernando, arcipreste de Frías, cuando entre sus donaciones deja dos maravedíes para "...San Millán..." ${ }_{82}$. Estas relaciones con el monasterio de la Rioja podrían explicar que la historia del venerable ermitaño fuera narrada en la portada de la iglesia, y hace cuestionarse si el pago efectivo del impuesto no tendría lugar en el atrio del templo.

El tono moralizante del relato de San Millán enlaza con las representaciones de condenados, animales, monstruos y luchas que ocupan las restantes dovelas conservadas en la tercera arquivolta y en los fondos del museo. Algunas piezas son de más fácil identificación, como es el caso del avaro arrastrado por dos demonios o de un per- 


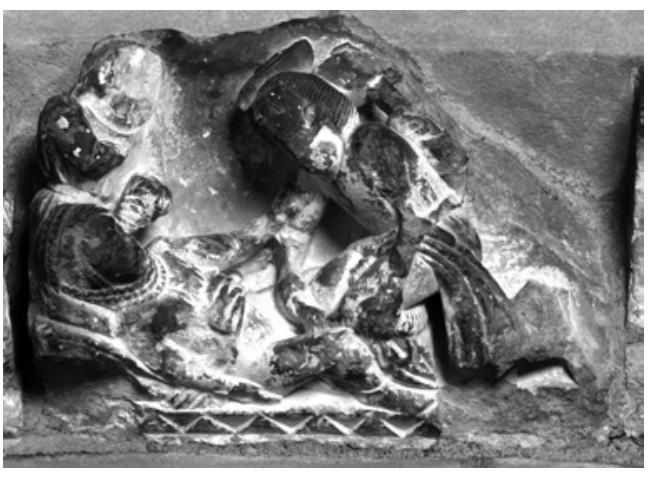

Fig. 15. Escena sin identificar. Portal de San Vicente de Frías (Burgos). Los Claustros. Nueva York

sonaje grotesco que personifica a la vez los pecados de lujuría y avaricia, puesto que carga con un saco de monedas mientras es mordisqueado por serpientes ${ }^{33}$ (fig. 14). Entre los animales se reconocen un buey, un cérvido galopante, un felino que se lame, una arpía decapitada, una criatura con plumas muy mutilada y un híbrido de león con cabeza humana que se enfrenta a un guerrero (fig. 12). El motivo del combate se repite también en una lucha de púgiles y en los capiteles con arpías, híbridos y caballeros enfrentados. Sin embargo, la presencia de una tregua domini que se interpone entre dos guerreros recuerda la prohibición de los enfrentamientos en el interior de la iglesia e incide en el carácter negativo que llevan aparejados los motivos relacionados con la guerra ${ }^{84}$ (figs. 11 y 14).

Igualmente reprochable parece ser la acción que tiene lugar en la dovela intercalada en el ciclo de San Millán que Rorimer identificó como "el monje herido", pensando que formaría parte del mismo ciclo85 (fig. 15). Es necesario ver la escena muy de cerca para reconocer a los personajes que la integran. Una mujer, con tocado de barboquejo, yace semidesnuda mientras un personaje masculino se cierne sobre ella con los genitales al descubierto y en postura de subirse o bajarse las calzas. Flanquean la escena otros dos, muy deteriorados. A la derecha del hombre tan sólo se conserva una mano que sostiene una maza, y detrás de la mujer, una figura descabezada parece agarrarle un mechón de pelo. Esta escena ha llamado la atención de Jacqueline Jung, que propone algunas explicaciones para los distintos personajes, que incluyen la violación y el adulterio, pero es consciente de la dificultad que entraña no conservar el ciclo completo ${ }^{86}$. En mi opinión, esta representación podría encontrar un paralelismo en la igualmente enigmática pila bautismal de Rebanal de Llantas, cuyos relieves coinciden con algunos de los de la portada, como es el caso de la pelea de púgiles, la lujuria, la tregua domini y una pareja desnuda que se abraza observada por dos figuras ${ }^{87}$.

Testigos de esta escena, y testigos de cuanto acontece en la portada son las dieciséis cabezas que asoman en la última arquivolta, catálogo caricaturesco de los estamentos más altos, cuyas muecas glosan cuanto acontece en el resto de la portada (fig. 16).

\section{Fragmentos engarzados en otro tiempo}

Cabe preguntarse, lejos de las orillas del Hudson, y a orillas del Ebro, cómo hubieran visto los habitantes de una Frías de mediados del siglo XIII las mismas esculturas. El momento de florecimiento y esplendor que vivió la ciudad se plasmaría en el crecimiento de la población, la consagración de numerosas iglesias, la promoción del mercado o en la obra escultórica de San Vicente. Los relatos que pueblan las arquivoltas de la portada mantenían un diálogo con una población formada mayoritariamente por agricultores y comerciantes, representados por el Concejo de la villa. Esta audiencia se vería reflejada en las imágenes de la portada, y entendería las esculturas en función de la idiosincrasia particular de la villa.

$Y$ es que la nueva villa de Frías era una ciudad de comerciantes, como indicaba su propio fuero. Ya se explicó anteriormente que en él se hacía más hincapié en los derechos mercantiles y relacionados con las tasas que en los derechos de caballeros y militares, a quienes apenas menciona. Una villa que creció muy rápidamente, con uno de los tres únicos mercados de la Bureba y con una judería importante era una población de mercaderes ${ }^{8}$.

Precisamente los mercaderes, los judíos, los marchantes, los comerciantes, todos aquellos que verían prosperar sus riquezas con el crecimiento de la villa se verían reflejados también en las imágenes de la portada del templo: en el avaro que sufre en el infierno, o en el usurero que 


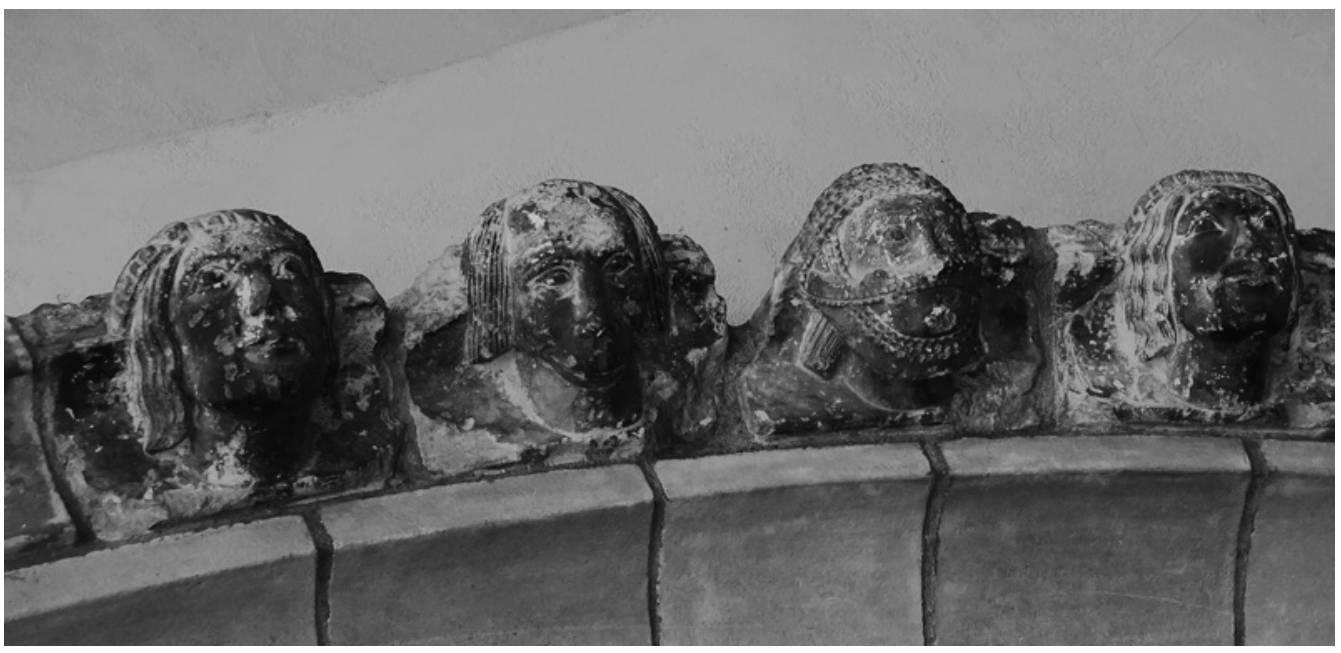

Fig. 16. Friso de cabezas del Portal de San Vicente de Frías (Burgos). Los Claustros. Nueva York

todavía aferra su gran bolsa de monedas mientras serpientes y sapos se retuercen a su alrededor mordisqueándole y corroyéndole el alma. Esta imagen prolifera en las iglesias urbanas, donde no sólo se recuerda a los mezquinos cicateros que la avaricia les valdrá las más duras penas del infierno, sino que también se alerta a peregrinos y pasantes contra los peligros de confiar en estas malas gentes ${ }^{89}$.

Los mensajes de la portada son claros, no hay complicados discursos tipológicos ni teológicos, ni visionarios. Las imágenes están dirigidas a un público variado, que hablaba romance, al que le era más fácil entender un discurso narrativo simple: el lenguaje sencillo de los evangelios, donde las escenas pueden ser fácilmente reconocidas por el espectador, al estar ordenadas disponiendo una historia que fluye de forma secuencial, sucesión de microrrelatos engarzados como las estrofas de una Biblia romanceada.

También, cual si de un romance se tratara, se presenta la leyenda monástica de San Millán, la historia de un pastor, que tras ser iluminado por San Felices de Bilibio se convirtió en ermitaño y dedicó su vida a la oración, a luchar contra el diablo y a realizar milagros. Una historia, que parece no haber tenido mucha repercusión iconográfica en la zona y ${ }^{90}$, sin embargo, semeja haber llegado hasta el valle de Tobalina, en el que los habitantes del alfoz de Petralada todavía pagaban tributo al monasterio en el siglo XIII, en agradecimiento por aquel milagro acaecido en la batalla de Hacinas tres siglos antes cuando Fernán González debió luchar contra los moros.

Las batallas también tienen cabida en esta portada que critica la violencia. En una villa, pensada como parte de un conjunto fronterizo para intentar estabilizar los límites con el vecino reino de Navarra, el tema de la lucha ecuestre está presente en uno de los capiteles del castillo y se repite entre los capiteles de la iglesia91. La presencia de este motivo en la portada se antoja conservadora, haciéndose eco de una tradición ampliamente extendida por el reino, pero que aquí es neutralizada por la presencia de la tregua dómini, que aboga por una solución no beligerante para la resolución de conflictos.

Al fin y al cabo, aunque Alfonso VIII pretendía crear una barrera protectora en la zona del Alto Ebro, también se esforzó en convertir la zona en un núcleo comercial fuerte donde la presencia militar era eminentemente débil. Por esta razón, se podría leer en la imagen de la tregua de Dios una referencia no sólo a la paz en tiempos de guerra, sino al acto de interceder y arbitrar, a la acción del juez, que se interpone entre dos personas enfrentadas y se encarga de intermediar en las disputas, ya que entre las actividades que se efectuaban frente a la iglesia, bajo la atenta mirada de los bustos pétreos, estaban registrados los juramentos que se realizaban antes de los juicios. A principios del siglo XIII, varias iglesias son 
mencionadas en los fueros haciendo referencia a este propósito juradero, como es el caso de Frías, pero también el de Medina de Pomar o el de Miranda de Ebro"2.

Esos rostros que parecen juzgar con sus ojos almendrados, se convierten ellos mismos en objeto de crítica. Las muecas grotescas y caras simiéscas convierten en sátira al estamento más alto, que también -como se aprecia en innumerables portadas- puede ser el que caiga más bajo en los fuegos infernales. Estas caricaturas de la nobleza y el clero podrían evocar las luchas de poderes, dado que la villa regia y el concejo habían sido creados para combatir el poder excesivo que tenían los poderes señoriales en el norte de Castilla93.

Estas imágenes se encuentran ahora a cinco mil quilómetros de distancia de su lugar originario y cada día son observadas por cientos de turistas como parte de un claustro románico catalán. Ya cuando Arthur K. Porter vio estas piezas en la instalación de 1924, no pudo evitar relacionarlas con los ejemplos más paradigmáticos del románi- co castellano, lejos todavía de pensar que los ojos que tallaron estas esculturas podían haberse posado anteriormente sobre las nuevas tendencias desarrolladas en la catedral de Burgos ${ }^{94}$.

Los americanos rescataron estas piedras de la intemperie en un momento en que la ciudad de Frías o la Comisión de Monumentos no se hubieran podido encargar de protegerlas. El Museo de los Claustros les concedió un lugar privilegiado con efecto sorpresa, pues para poder admirarla el visitante debe girarse nada más entrar en "el gran claustro de Cuxá". Y cuando lo hace, ve una serie de piedras encajadas en un puzzle, algunas de ellas de exquisita factura, y otras muchas apaleadas por la acción del tiempo. Es poco lo que se conserva de aquella entrada monumental, que durante siglos acogería a numerosos feligreses en el seno de su iglesia; ahora es tan sólo un testimonio más, un vestigio de lo que nos queda de aquella época de esplendor en el Alto Ebro castellano, y una demostración del esfuerzo humano por preservar la historia, al mismo tiempo que la descontextualiza, relegando su significado al olvido. 


\section{NOTAS}

* El presente texto deriva del trabajo de fin de máster La iglesia de San Vicente de Frías: una aproximación dirigido por Rocío Sánchez Ameijeiras, en el Máster de Estudios Medievales Europeos: Imágenes, Textos y Contextos de la USC, presentado durante el curso académico 2012-2013.

1 Este trabajo no hubiera sido posible sin la ayuda de las siguientes personas e instituciones, que contribuyeron a que Burgos y Nueva York pudieran estar un poco más cerca: Rocío Sánchez Ameijeiras, mi directora, Haleigh Spazojevich y Pablo Ordás, sin cuyas fotos de la portada no hubiera podido escribir este trabajo. Los responsables del Archivo Diocesano de Burgos, el Archivo Provincial de Burgos, el Archivo Histórico de Burgos, el Archivo Histórico de la Catedral de Burgos y el archivo de la Institución Fernán González, Christinne Brennan, Senior Research Associate en el Museo Metropolitano de Nueva York y Emeline Baude Sherman Fairchild Assistant Conservator en el Museo de los Claustros.

2 Las primeras descripciones breves de la portada fueron llevadas acabo por Joseph Breck y James Rorimer. Joseph Breck, "The New Galleries of Mediaeval and Renaissance Art," The Metropolitan Museum of Art Bulletin 19, no. 10 (1924): 231-235. James Rorimer, The Cloisters: the building and the collection of Medieval Art in Fort Tyron Park (New York: Metropolitan Museum of Art, 1963 [1938]), 72-73. En los estudios españoles que intentan compendiar el románico burgalés la portada suele quedar relegada a un segundo plano, como en: Fernando Cana García, Iconografía del románico burgalés (Madrid: Editorial de la Universidad Complutense de Madrid, 1992). Gerardo Boto Varela, Ornamento sin delito: Los seres imaginarios del claustro de silos y sus ecos en la escultura románica peninsular (Burgos: Amabardos Ediciones 2001). Pedro Luis Huerta Huerta, "Frías" en Enciclopedia del románico en Castilla y León. Burgos (Aguilar de Campoo: Fundación Santa María la Real, 2002) 1745-1752. En los últimos años se han realizado trabajos más profundos que ahondan en las esculturas de la portada, pero que no han sido publicados. Marta Poza Yagüe le dedica un pequeño epígrafe en su tesis doctoral: Marta Poza Yagüe, "La portada historiada en Castilla y León del Románico pleno al Tardorrománico y estilo 1200" (PhD diss., Universidad Autónoma de Madrid, 2004), Vol II. 823-826. Jacqueline Jung escribió una memoria con una descripción y un estudio pormenorizado de la iconografía de la portada, que se puede consultar en el Archivo del Museo Metropolitano (AMM): Jacqueline Jung, "Portal of San Vicente de Frias Martir. Report for the Jane and Morgan Whitney Fellowship" (AMM, 2004). Y yo misma analicé con detenimiento la portada en mi trabajo de fin de máster: Marina Garzón, "La iglesia de San Vicente de Frías: una aproximación", (TFM. Máster en Estudos Medievais Europeos, Universidade de Santiago de Compostela, 2013). Finalmente, algunas de las conclusiones de Jacqueline Jung serían publicadas en Jacqueline Jung, "42. Corbel with female head," in Set in Stone. The face in medieval sculpture, ed. Charles T. Little (New York: Metropolitan Museum, 2006) 110-111. Jacqueline Jung, "The Portal of San Vicente Martír in Frías: Sex, Violence, and the Comfort of Community in a Thirteenth-Century Sculpture Program at The Cloisters," in Theologisches Wissen und die Kunst, ed. Rebecca Müller, Anselm Rau and Johanna Scheel (Berlin: Gbr. Mann Verlag, 2015) 369-382.

3 Jung, "The Portal of San Vicente," 371.

4 Su nombre hace referencia a la piedra toba característica de la región y utilizada en la construcción de la iglesia, que ha dado lugar a tantos otros topónimos como Tobalinilla, Tobar o Tobera. Para más información sobre esta piedra ver: Mara José González Amuchastegui y Enrique Serrano Cañadas, "Tobas y patrimonio en la ciudad de Frías (Burgos). El patrimonio geomorfológico como parte del conjunto histórico" en Avances de la Geomorfología en España 2012-2014, ed. Susanne Schnabel y Álvaro Gómez Gutiérrez (Cáceres: Sociedad Española de Geomorfología, 2014) 425-428.

5 Inocencio Cadiñanos Bardeci, Frías, Ciudad en Castilla (Frías: Ayuntamiento de Frías, 1999) 101-105.
6 Cadiñanos, Frías. Inocencio Cadiñanos Bardeci, Frías y Medina de Pomar (historia y arte) (Burgos: Institución Fernán González, 1978).

7 Archivo Diocesano de Burgos (ADB), Legajo X, Documento 15. En este documento datado en 1572 se trata la quema de unos privilegios en un incendio habido en la ciudad", que además del archivo hizo arder varias casas.

8 José María Monsalvo Antón, "Los territorios de las villas reales de la vieja Castilla, ss. XI-XIV: antecedentes, génesis y evolución. (Estudio a partir de una docena de sistemas concejiles entre el Arlanza y el Alto Ebro)," Studia historica. Historia medieval 17 (1999): 49-50. Iñaki Martín Viso, Poblamiento y estructuras sociales en el norte de la Península Ibérica:(Siglos VI-XIII) (Salamanca: Ediciones Universidad de Salamanca, 2000) 296-302. Ignacio Álvarez Borge, Cambios y alianzas: La politica regia en la frontera del Ebro en el reinado de Alfonso VIII de Castilla (11581214) (Madrid: CSIC, 2008) 162-167.

9 Álvarez Borge, Cambios y alianzas, 147.

${ }^{10}$ La inconveniencia de estas medidas tiene su confirmación en el testamento que el rey dictó en 1204 mientras sufría una severa enfermedad de la que creyó que no habría de recuperarse. Consciente como era de que la creación de estas villas había afectado mucho a los poderes señoriales, ordenó destruir las nuevas poblaciones. Sin embargo, tras recuperarse de su enfermedad cambiaría de opinión, y ninguna de las villas sería destruida por muy inconveniente que resultara a los nobles. Álvarez Borge, Cambios y alianzas, 147-148.

11 Ejemplo de estas disputas lo constituye el llamado "Pleito de los cien testigos", cuyas actas del siglo XIII se han conservado. Este material de riqueza extraordinaria no sólo incluye las entrevistas realizadas a los personeros de las partes, sino que comprende la transcripción de procesos anteriores relacionados con la susodicha pesquisa. Álvarez Borge, Cambios y alianzas, 187. Ver también Isabel Alfonso Antón y Cristina Jular Pérez-Alfaro, "Oña contra Frías o el pleito de los cien testigos: Una pesquisa en la Castilla del siglo 
XIII," Edad Media: Revista de Historia 3 (2000): 61-88.

12 ".. pro illo vestro castello de Fridas...". Álvarez Borge, Cambios y alianzas, 162. Documento editado en: Julio González González, El reino de Castilla en la época de Alfonso VIII. Estudio y documentos (Madrid: Escuela de Estudios Medievales, 1960) T.3. doc, 712.

${ }^{13}$ Iñaki Martín Viso analiza la trayectoria del asentamiento desde que tan solo se mencionan unas viñas y recoge los siguientes documentos: Aurelio Ubieto Arteta, Cartulario de San Millán de la Cogolla: (759-1076) Nalencia: Anubar, 1976) (SMI) docs 8 (01.05.867) y 19 (899-912), hasta que se entiende como núcleo poblacional: Juan del Álamo, Colección de San Salvador de Oña (822-1284) (Madrid: CSIC, 1950) (OÑA) doc. 10 (27-02-1011) y doc 211 (25.12.1152). Martín Viso, Poblamiento, 113, 296-299.

14 Se conservan dos versiones del fuero de Frías. La primera de ellas es una confirmación de Fernando III en 1217 del documento expedido por Alfonso VIII en 1202, este texto obvia las disposiciones oficiales del Fuero de Logroño y únicamente registra las ordenanzas específicas para los habitantes de Frías. La segunda, una versión larga sin datar, consiste en una copia del fuero de Logroño con las nuevas cláusulas y las modificaciones pertinentes. Como opina Gonzalo Martínez Díez, probablemente se tratara de un documento elaborado por el concejo, que obtuvo una copia del fuero de Logroño y vertió por escrito su propio "Fuero de Frías". Este documento nunca sería ratificado por ningún rey, por esta razón, a juicio de este autor, "...no se trata más que de una explicitación fidelísima de carácter privado del contenido implícito del diploma del 8 de abril de 1202". Gonzalo Martínez Díez, Fueros locales en el territorio de la provincia de Burgos (Burgos: Caja de Ahorros Municipal de Burgos, 1982) 68-69. 41

${ }^{15}$ Monsalvo Antón, "Territorios,"

${ }^{16}$ Álvarez Borge, Cambios y alianzas, 163.

17 Los habitantes de la Muela, por la molestia causada debido a las continuas subidas y bajadas a lo alto de la colina, pagarían la mitad de renta y estaban exentos de pagar el fonsado y el apellido. "Has siquidem absolutiones facio ego illis populatoribus de la Mola pro maximo labore quem ibi substinent ascendendo et descendendo cum rebus suis". Martínez Díez, Fueros locales, 172.

18 Álvarez Borge, Cambios y alianzas, 162-164.

19 Inocencio Cadiñanos Bardeci, El Monasterio de Santa María de Vadillo (Frías: Ayuntamiento de Frías, 2009) doc. 1.

${ }^{20}$ Cadiñanos Bardeci, Vadillo, 4.

${ }^{21}$ Cadiñanos Bardeci, Frías, 124.

22 Frías debió de erigirse en arciprestazgo en una fecha muy temprana, pues ya Diego de Haro es documentado como arcipreste de Frías, y en los documentos del ADB se mencionan otros arciprestes del siglo XIII, como "Fernant Gonzalez arcipreste" (Legajo XXXV, Doc. 7, 1241) o "Fernando arcipreste de Frías" (Legajo XXXV, Doc. 12, 1280)

${ }^{23}$ Firma documentos en 1211 y 1219. Cadiñanos Bardeci, Vadillo, 4-6.

${ }^{24}$ Cuando Guiralt de Perella dona un molino a cambio de que los clérigos misacantanos de San Vicente "...canten misa por mi al altar de Sant Nicholas" ADB: Legajo XXXV, Documento 4.

${ }^{25} \mathrm{El}$ documento recoge también una serie de instrucciones para su enterramiento y especifica el dinero que se ha de pagar a los clérigos que habían de oficiar en él. Debían ir los misacantanos, los subdiaconos y se pide a los sacristanes que tañan las campanas ADB: Legajo XXXV, Documento 12.

${ }^{26}$ Celestino Quintana, Historia de la Ciudad de Frías (Vitoria: Establecimiento Tipográfico de Casiano Jáuregui, 1887) 42

27 Cadiñanos Bardeci, Frías, 98116.

${ }^{28}$ ADB: Frías. Libros de Fábrica de 1803-1844 Folio $175 \mathrm{v}$.

${ }^{29}$ ADB: Frías. Libros de Fábrica de 1865-1966 Folios 23 v y $25 \mathrm{v}$.

${ }^{30}$ ADB: Frías. Libros de Fábrica de 1865-1966 Folio 48 r y $48 \mathrm{v}$.

31 Archivo Provincial de Burgos: APB: Expediente de la obra de reparación de la Iglesia de Frías (1906-1916).
32 APB: Expediente de la obra de reparación de la Iglesia de Frías (19061916).

${ }^{33}$ Es probable que se conserve evidencia escrita en forma de cuentas en alguna parte. Quizás las ventas no consten en los libros de Fábrica, pero sí que debería aparecer el dinero destinado a la obra de la iglesia. Sin embargo, todos los documentos del Archivo Diocesano de Burgos de menos de 100 años están sujetos a confidencialidad y no pueden ser consultados.

34 "Carta de Luciano Huidobro a James Rorimer" AMM. [Luciano Huidobro, 1939]

35 Jose Calleja, el Arquitecto Provincial que se había encargado del diseño y construcción de la portada de Frías era uno de los vocales de la Comisión Provincial de Monumentos, por esta razón no es aventurado suponer que fuera él quien completara el informe. Al fin y al cabo, había estado viajando a la ciudad entre los años 1906 y 1916 para participar en la dirección de los trabajos, por lo que debía de conocer bien el estado de las ruinas. APB, Informe de la Restauración de la Iglesia de San Vicente de Frías (1906-1916)

36 Agustín Villasante, Historia de la Ciudad de Frías (Buenos Aires: Talleres gráficos de Olivieri y Domínguez, 1944) 157. Además de las esculturas, se vendieron tres ternos muy valiosos y estuvieron cerca de desprenderse de la reja de la capilla de la Visitación. Tanto Agustín Villasante como Cadiñanos Bardeci (posiblemente siguiendo a Villasante) hacen referencia al papel que jugó el Cardenal Benlloch en las enajenaciones de Frías. Cadiñanos Bardeci, Frías, 105. El señor Juan Benlloch, obispo de Urgel, no sería nombrado arzobispo de Burgos hasta 1919. Si es verdad que fue él el encargado de vender las piezas, entonces la venta se habría realizado con posterioridad a esa fecha.

37 Institución Fernán González. (IFG) Actas de la Comisión Provincial de monumentos. 19 de febrero de 1923.

${ }^{38}$ Maria José Martínez Ruíz, que estudió en su tesis doctoral la enajenación del patrimonio en Castilla y León, dedica un pequeño apartado a las esculturas de Frías y, para ello, debió de rastrear todos los libros de actas y do- 
cumentos sin catalogar de la Institución Fernán González. En 2008 publicó sus hallazgos más relevantes en dos volúmenes de gran valía, pues su magnífico trabajo y su minuciosidad a la hora de citar permiten localizar rápidamente las fuentes -todavía pendientes de ser organizadas- en el archivo de la institución castellana. Maria José Martínez Ruiz, La enajenación del patrimonio en Castilla y León (1900-1936) (Valladolid: Junta de Castilla y León, 2008) T. 1, 81-84.

${ }^{39}$ IFG, Actas de la Comisión Provincial de monumentos. 26 de junio de 1923.

40 "Carta de Joseph Breck a Henry Walters", AMM (Carpeta Frías). [Joseph Breck, 8 de marzo de 1923]

${ }^{41}$ Christine E Brennan, "The Brummer Gallery and the business of art," Journal of the History of Collections 27, no. 3 (November 2015): 463. Christine Brennan ha estudiado con detenimiento la historia del galerista Joseph Brummer, muchas de cuyas piezas se encuentran hoy día en el Museo Metropolitano. Ver también: James N. Carder, A Home of the Humanities. The collecting and patronage of Mildred and Robert Wood Bliss (Washington DC: Dumbarton Oaks Museum Publications, 2010). Caroline Bruzelius and Jill Meredith, The Brummer Collection of Medieval Art (Durham: Duke University Press, 1991). William H. Forsyth, "The Brummer Brothers: an Instinct for the Beautiful," Art News 73, no. 8 (1974): 106-107.

42 "...the most striking exhibit in the room". Breck, "New Galleries", 231.

43 Timothy B. Husband, "Creating the Cloisters" The Metropolitan Museum Art Bulletin 70, no 4 (Spring 2013). Peter Barnet and Nancy Wu, The Cloisters. Medieval Art and Architecture (New York: Metropolitan Museum of Art, 2005) 9-13.

${ }^{44}$ Rorimer, The Cloisters, 72-73.

45 En el Archivo del Museo de los Claustros se conservan algunos apuntes, así como fotos y planos sobre el proceso de reconstrucción de la portada. AMC (Carpeta Frías). Al no poder encajar todas las piezas, algunos restos escultóricos se conservan en los fondos del museo.
${ }^{46}$ Barnet and Nancy, The Cloisters, 15

${ }^{47}$ Ver nota 3.

48 Quintana, Historia, 42.

${ }^{49}$ Charlotte de Charette, "La diffusion de l'art du second atelier de sculpture de Silos dans le nord de l'Espagne, " (PhD diss., Université Michel de Montaigne Bordeaux 3, 2014) 66-77, 88-95.

50 María P. Moreno Alcalde, "Puertas del cielo. El arco lobulado en el arte medieval español," Goya: Revista de arte 295-296 (2003): 225-244. Para las iglesias navarras ver: Javier Martínez de Aguirre y Asunción de Orbe Sivatte, "Consideraciones acerca de las portadas lobuladas medievales en Navarra. Santiago de Puente la Reina, San Pedro de la Rúa de Estella y San Román de Cirauqui," Principe de Viana 48, no. 180 (1987): 47-49. Para Zamora: Carlos Domínguez Herrero, El románico zamorano en su marco del noroeste. Iconografía y simbolismo (Zamora: Gráficas Lope, 2002)141-142.

${ }^{51}$ Otra razón que pudo influir es el hecho de que no se conserva una clave que se ajuste a este diseño.

52 Aunque anteriores a Frías, estos ejemplos cercanos deben tenerse en cuenta, puesto que no sólo evidencian que el apuntamiento de las portadas era habitual, sino que muestran una organización de las dovelas que combinan esculturas tanto en posición vertical como en posición radial, como en el caso fredense. Sobre estas iglesias se puede consultar: José Manuel Rodríguez Montañés, "Vallejo de Mena" en Enciclopedia del Románico en Castilla y León. Burgos, dir. Miguel Ángel García de Guinea y José María Pérez González (Aguilar de Campoo: Fundación Santa María la Real, 2002) 2103-2106. Charette, "La diffusion de Silos," 110-116.

53 Debido a la relación de Alfonso VIII con el fuero de Frías y el desarrollo de la ciudad, Rorimer entiende que muy probablemente este monarca también promoviera la construcción de la iglesia y, por lo tanto, de su portada. Rorimer, The Cloisters, 72-73. Esta idea será recogida también por Jung: Jung, "The Portal of San Vicente," 370.

${ }^{54}$ Ambos autores en sus respectivos trabajos se enfrentan al problema de la utilización del término estilo, dado que distintos escultores pueden trabajar con un mismo estilo. Por esta razón, Esther Lozano, cuando analiza la escultura de la portada de Santo Domingo de Soria, realizada toda en un mismo estilo, opta por referirse a "modos" de trabajar, o "modos" de hacer para distinguir la presencia de distintos artífices. Esther Lozano, "La portada de Santo Domingo de Soria. Estudio formal e iconográfico." (PhD diss., Universitat Rovira i Virgili, 2003), 613-614. Por otro lado, Daniel Rico Camps al acercarse a la escultura borgoñona en Castilla utiliza el término temperamento para describir las formas en que un mismo estilo puede ser entendido, pero aceptando que un mismo estilo con un mismo temperamento puede tener varias manos. Daniel Rico Camps, "Reflexiones sobre la decantación hispana de la escultura borgoñona," en Maestros del románico en el Camino de Santiago, coord. Pedro Luis Huerta Huerta (Aguilar de Campoo: Fundación Santa María la Real, 2010), 122-124.

${ }^{55}$ Las piezas que se corresponden con los ábacos y los sillares bordurados con puntas de diamante presentan sendos relieves ocultos en su parte posterior, que no pueden adscribirse a estos escultores. Los ábacos con decoración vegetal ocultan un taqueado jaqués, y los sillares esconden capiteles ornamentados. En el montaje del Museo de los Claustros se acondicionaron dos ventanitas para que los visitantes pudieran observar estos extraños elementos que no casan con los ejemplos de la zona. En su momento, Joseph Breck interpretó que estos capiteles debían pertenecer a una construcción anterior de la iglesia, y que habían sido reaprovechados al rehacer la portada. Breck, "New Galleries", 232. Debido a su dudosa vinculación con el resto de las esculturas, excede el propósito de este trabajo abordar el estudio de estos capiteles, que esperan ser tratados en investigaciones posteriores.

${ }^{56}$ Charette, "La diffusion de Silos."

57 Se pueden incluir en estos ciclos por similitud fisionómica algunos fragmentos conservados ahora en los fondos del museo, en los que se reconoce un busto de aire sorprendido y tres personajes expectantes que probable- 
mente formarían parte de una multitud mayor.

58 Henrik Karge, La catedral de Burgos y la arquitectura del siglo XIII en Francia y España, (Valladolid: Junta de Castilla y León, 1995 [1989]) 106-109.

59 También se podría vincular con un pequeño fragmento conservado en depósito que representa a un personaje sentado que sostiene una espada.

60 Karge, La Catedral de Burgos, 103-109.

${ }^{61}$ Clementina Ara Gil vinculó una serie de urnas funerarias procedentes de Palencia con los talleres del Sarmental de la Catedral de Burgos en: Clementina Julia Ara Gil, "Un grupo de sepulcros palentinos del siglo XIII. Los primeros talleres de Carrión de los Condes, Pedro Pintor y Roi Martínez de Bureba, " en Alfonso VIII y su época. II Curso de Cultura Medieval, coord. Jaime Nuño González (Aguilar de Campoo: Centro de Estudios del Románico,1992) 21-25. Este tema lo retomó Rocío Sánchez al analizar un sepulcro del Museo Arqueológico Nacional que compara con el arca sepulcral de San Pedro de Cisneros. En este estudio, señala el parecido de estas esculturas no solo con los referentes burgaleses, sino con ejemplos procedentes de Amiens. Los artistas reinterpretaron el lenguaje de las figuras monumentales, adaptándolo en pequeño formato por medio de paños formados por grandes planos y plegados en zig-zag con rigidez. Además, propone datar estos sepulcros a mediados del siglo XIII entre 1240 y 1250. Rocío Sánchez Ameijeiras, "Notas sobre un arca sepulcral gótica conservada en el museo arqueológico nacional," Boletín del Museo Arqueológico Nacional 12, no. 1-2 (1994):104-112.

${ }^{62}$ En los fondos del museo hay un séptimo capitel con arpías que coincide morfológicamente con los capiteles trilobulados de la portada.

${ }^{63}$ Estos capiteles pueden relacionarse iconográficamente con los capiteles del castillo de Frías, datados a comienzos del siglo XIII. Sin embargo, aunque resulta tentador adjudicárselos al mismo taller, es en esta comparación donde se hace patente el aire conservador de los capiteles del castillo, frente a la nueva plasticidad de la vegetación presente en los capiteles de la portada de Frías.

${ }^{64}$ Karge, La Catedral de Burgos, 103-109.

${ }^{65}$ Esta figura de torso mutilado no pudo ser encajada en la portada debido a sus grandes dimensiones. Apenas se aprecia un cinturón y parte del busto y de la cintura. En la parte inferior se intuyen unas ondas, único resto de unas nubes esponjosas, y es posible leer el fino fragmento de textura situado en la parte posterior como parte del ala de un ángel. Es imposible conocer el lugar de esta figura en la portada, pero debido a su tamaño podría haberse situado en una enjuta o pudo incluso estar en el interior de la iglesia.

${ }^{66}$ Rorimer, The Cloisters, 72-73. Jung, "The Portal of San Vicente," 370. Huerta Huerta, Frías, 1750-1572.

${ }^{67}$ Entre las personas que han trabajado esta portada Marta Poza es la única que propone una cronología tardía basándose tanto en el estilo como en la presencia de algunos episodios. Poza Yagüe, "La portada historiada," 826.

\section{${ }^{68}$ Ver nota 24}

${ }^{69}$ Tal y como señalé en la nota 2 , los análisis completos de todas las esculturas que se han realizado hasta la fecha están todavía sin publicar.

70 Jung, "The Portal of San Vicente," 376.

71 Rorimer, The Cloisters, 72-73.

72 Braulio de Zaragoza, Vita sancti Aemiliani, § 2-3.

73 San Millán fue un ermitaño del siglo VI considerado fundador del cenobio riojano del mismo nombre. Su vida y milagros fueron escritos en latín en el siglo VII por Braulio de Zaragoza, y vertidos al romance en el siglo XIII por Gonzalo de Berceo, que escribiría en cuaderna vía una versión amplificada de la Vita Aemiliani de Braulio. Comparando estas dos fuentes, se puede apreciar, como se verá, cómo las versiones visuales de la vida del santo riojano hubieron de jugar un papel importante en el enriquecimiento de la versión literaria romance con respecto a la latina. José Oroz Reta, "Sancti Braulionis Caesaraugustani episcopi Vita sancti Aemiliani," Perficit 9 (1978):165-215. Brian Dutton,
La vida de San Millán de la Cogolla de Gonzalo de Berceo: Estudio y edición crítica (London: Tamesis Books, 1967) 85-159. En cuanto a la iconografía de este santo, se han conservado algunos ejemplos en soportes variados, entre los que destacan: dos miniaturas del siglo X, Soledad de Silva y Verástegui, "Miniaturas inéditas de la "Vida de San Millán de la Cogolla" en un códice del siglo X," Berceo 124 (1993): 61-66. La arqueta de marfíl de San Millán, s. XI) Julie Ann Harris, "Culto y narrativa en los marfiles de San Millán de la Cogolla," Boletín del Museo Arqueológico Nacional 9 (1991) 68-85. Frescos y tímpano de la iglesia de San Millán de Segovia, (s. XII-XIII), Fernando Gutiérrez Baños, "Un mural románico en la iglesia de San Millán de Segovia: transmigración de modelos textuales y de modelos visuales en el arte medieval," Hortus artium medievalium 19 (2013): 387-401. El cenotafio de San Millán en el monasterio de Yuso, Rocío Sánchez Ameijeiras, "Imagery and Interactivity: Ritual Transaction at the Saint's Tomb," in Decorations for the Holy Dead. Visual embellishment on tombs and shrines of saints ed. Stephen Lamia y Elizabeth Valdez del Alamo (Turnhout: Brepols, 2002) 21-38. Las tablas de San Millán del Museo de Logroño (s. XIV), María de los Ángeles Heras y Núñez, "Las tablas de San Millán de la Cogolla," en Segundo Coloquio sobre Historia de La Rioja: Logroño, 2-4 de octubre de 1985, (Logroño: Colegio Universitario de la Rioja, 1985) vol. III, 57-71.

${ }^{74}$ Berceo, La vida de San Millán, § 203-223.

75 Para más información sobre la influencia del arte en la Vida de San Millán de Gonzalo de Berceo ver: Sánchez Ameijeiras, "Imagery and Interactivity" y Heras y Nuñez, "La literatura emilianense y el arte medieval riojano", 224226.

76 Ambos autores, el monje Fernando y Gonzalo de Berceo, procedían del propio monasterio. Además, el monje Fernando ha sido identificado como el falsificador de los Votos de San Millán, como se comentará más abajo. Dutton, La vida de San Millán, 51-61.

77 Berceo, La vida de San Millán, § 203-223. 
${ }^{78}$ Estos demonios recuerdan, en parte, los tenantes esculpidos del cenotafio de San Millán. Sánchez Ameijeiras, "Imagery and Interactivity", 24.

${ }^{79}$ El Monasterio de San Millán de la Cogolla, institución destacada de los siglos X al XIII velaba los restos del santo riojano $y$, además de orquestar un culto sepulcral promocionando su capacidad de realizar milagros, intentó nutrir sus arcas, ideando la "invención" de los Votos de San Millán. En algún momento de finales del siglo XII o principios del XIII, generaron la leyenda que atribuía al santo una milagrosa aparición en la batalla de Hacinas para auxiliar al conde Fernán González, logrando así la victoria cristiana. Con ello se pretendía que los habitantes de Castilla pagasen un Voto al monasterio en señal de agradecimiento por el milagro. José Ángel García de Cortázar, El Dominio del monasterio de San Millán de la Cogolla (siglos $X$ a XIII): introducción a la historia rural de Castilla altomedieval (Salamanca: Universidad de Salamanca, 1969) 318323.

${ }^{80}$ Dutton, La vida de San Millán, 163-195 y Aurelio Ubieto Arteta, "Los Votos de San Millán," en Homenaje a Jaime Vicens Vives (I) (Barcelona: Universidad de Barcelona, 1965) 309-324. Martín Viso, Poblamiento, 298.

${ }^{81}$ García de Cortázar, San Millán de la Cogolla, 135. En una nota al pie menciona un documento que confirma el intercambio de unas tierras entre el monasterio de San Millán y el concejo de Frías en 1227. San Millán, leg. 18, nº 65.

${ }^{82}$ ADB: Legajo XXXV, Documento 12.

${ }^{83}$ Sobre la iconografía del avaro, y la representación de Judas como mercader en el camino de Santiago: Beatriz Mariño, "'Judas mercator Pessimus': Mercaderes y peregrinos en la imaginería medieval," en Los Caminos y el Arte: actas: VI Congreso Español de Historia del Arte: CEHA: Santiago de Compostela, 16-20 de Junio de 1986, (Santiago de Compostela: Universidade de Santiago de Compostela, 1989) 31-41. En el románico burgalés son numerosos, y en Miranda de Ebro, por ejemplo, se conserva también un avaro mordido por serpientes.

${ }^{84}$ Margarita Ruiz Maldonado, El caballero en la escultura románica de Castilla y León (Salamanca: Universidad de Salamanca, 1986) 28-34.

85 Rorimer, The Cloisters, 72-73. Debo agradecer a Emeline Baude que me facilitara una foto de esta dovela, en la que se puede apreciar de cerca su singular iconografía.

${ }^{86}$ Jung, "The Portal of San Vicente," 381-382.
${ }^{87}$ Garbiñe Bilbao identifica a la figura femenina que empuja a la mujer desnuda como una alcahueta. Garbiñe Bilbao López, "Iconografía de la lujuria. La mujer y los espectáculos en la pila bautismal románica de Rebanal de las Llantas (Palencia)," Goya 259-260 (1997): 454.

${ }^{88}$ Cadiñanos Bardeci, Frías, 54.

${ }^{89}$ Mariño, "Judas," 31-41.

90 Harris, "San Millán". Sánchez Ameijeiras, "Imagery and Interactivity", Heras y Núñez, "La literatura emilianense".

91 A pocos quilómetros de la población, entre los peñascos, se elevaba todavía el castillo de Petralada, levantado por los navarros en 1040 en una de estas oleadas, en que el valle del Tobalina pasó a formar parte del reino vecino Cadiñanos Bardeci, Frías, 69.

92 La función juradera aparece recogida en los fueros de estas ciudades como en el caso de Frías: "Et si venerit alicuius homo de foris de omni parte qui inquirat iudicium de alicuius populator respondeat in sua villa uel in ecclesia Sancti Vicencii" Martínez Díez, Fueros locales, 172.

${ }^{93}$ Ver supra.

${ }^{94}$ Arthur K. Porter, Spanish Romanesque Sculpture (New York: Hacker Art Books, 1969 [1928]) 28. 


\section{REFERENCIAS}

Álamo, Juan del. 1950. Colección de San Salvador de Oña (822-1284). Madrid: CSIC. (OÑA)

Alfonso Antón, Isabel, and Cristina Jular PérezAlfaro. 2000. "Oña contra Frías o el pleito de los cien testigos: Una pesquisa en la Castilla del siglo XIII." Edad Media: Revista de Historia 3: 61-88.

Álvarez Borge, Ignacio. 2008. Cambios y alianzas: La política regia en la frontera del Ebro en el reinado de Alfonso VIII de Castilla (11581214). Madrid: CSIC.

Ara Gil, Clementina Julia. 1992. "Un grupo de sepulcros palentinos del siglo XIII. Los primeros talleres de Carrión de los Condes, Pedro Pintor y Roi Martínez de Bureba. " In Alfonso VIII y su época. II Curso de Cultura Medieval, coordinado por Jaime Nuño González, 21-52. Aguilar de Campoo: Centro de Estudios del Románico.

Barnet, Peter, and Nancy Wu. 2005. The Cloisters. Medieval Art and Architecture. New York: Metropolitan Museum of Art.

Bilbao López, Garbiñe. 1997. “Iconografía de la lujuria. La mujer y los espectáculos en la pila bautismal románica de Rebanal de las Llantas (Palencia)." Goya 259-260: 451-456.

Boto Varela, Gerardo. 2001. Ornamento sin delito: Los seres imaginarios del claustro de silos y sus ecos en la escultura románica peninsular. Burgos: Amabardos Ediciones.

Breck, Joseph. 1924. "The New Galleries of Mediaeval and Renaissance Art." The Metropolitan Museum of Art Bulletin 19, no. 10: 231235. https://doi.org/10.2307/3254963

Brennan, Christine E. 2015. "The Brummer Gallery and the business of art." Journal of the History of Collections 27, 3 (November) 455468.

Bruzelius, Caroline, and Jill Meredith. 1991. The Brummer Collection of Medieval Art, Durham: Duke University Press.

Cadiñanos Bardeci, Inocencio. 1978. Frías y Medina de Pomar (historia y arte). Burgos: Institución Fernán González.
Cadiñanos Bardeci, Inocencio. 1999. Frías, Ciudad en Castilla. Frías: Ayuntamiento de Frías.

Cadiñanos Bardeci, Inocencio. 2009. El Monasterio de Santa María de Vadillo. Frías: Ayuntamiento de Frías.

Cana García, Fernando. 1992. Iconografía del románico burgalés. Madrid: Editorial de la Universidad Complutense de Madrid.

Carder, James N. 2010. A Home of the Humanities. The collecting and patronage of Mildred and Robert Wood Bliss. Washington DC: Dumbarton Oaks Museum Publications

Charette, Charlotte de. 2014. "La diffusion de l'art du second atelier de sculpture de Silos dans le nord de l'Espagne." PhD diss., Université Michel de Montaigne Bordeaux 3.

Domínguez Herrero, Carlos. 2002. El románico zamorano en su marco del noroeste. Iconografía y simbolismo. Zamora: Gráficas Lope.

Dutton, Brian. 1967. La vida de San Millán de la Cogolla de Gonzalo de Berceo: Estudio y edición crítica. London: Tamesis Books.

Forsyth, William H. 1974. "The Brummer Brothers: an Instinct for the Beautiful." Art News 73, 8: 106-107.

García de Cortázar, José Ángel. 1969. El Dominio del monasterio de San Millán de la Cogolla (siglos X a XIII): introducción a la historia rural de Castilla altomedieval. Salamanca: Universidad de Salamanca.

González Amuchastegui, Maria José, and Enrique Serrano Cañadas. 2014. "Tobas y patrimonio en la ciudad de Frías (Burgos). El patrimonio geomorfológico como parte del conjunto histórico." In Avances de la Geomorfología en España 2012-2014 editado por Susanne Schnabel y Álvaro Gómez

Gutiérrez, 425-428. Cáceres: Sociedad Española de Geomorfología.

González González, Julio. 1960. El reino de Castilla en la época de Alfonso VIII. Estudio y documentos. Madrid: Escuela de Estudios Medievales.

Gutiérrez Baños, Fernando. 2013. “Un mural románico en la iglesia de San Millán de Sego- 
via: transmigración de modelos textuales y de modelos visuales en el arte medieval." Hortus artium medievalium 19: 387-401. https://doi. org/10.1484/J.HAM.1.103592

Harris, Julie Ann. 1991. "Culto y narrativa en los marfiles de San Millán de la Cogolla." Boletín del Museo Arqueológico Nacional 9: 68-85.

Heras y Núñez, María de los Ángeles. 1985. "Las tablas de San Millán de la Cogolla." In Segundo Coloquio sobre Historia de La Rioja: Logroño, 2-4 de octubre de 1985, vol III, 5771. Logroño: Colegio Universitario de la Rioja.

Huerta Huerta, Pedro Luis. 2002. "Frías." In Enciclopedia del románico en Castilla y León. Burgos. 1745-1752. Aguilar de Campoo: Fundación Santa María la Real.

Husband, Timothy B. 2013. "Creating the Cloisters." The Metropolitan Museum Art Bulletin 70, no. 4 (Spring 2013).

Jung, Jacqueline E. 2004. "Portal of San Vicente de Frias Martir. Report for the Jane and Morgan Whitney Fellowship." Archivo del Museo Metropolitano.

Jung, Jacqueline E. 2006. "42. Corbel with female head." In Set in Stone. The face in medieval sculpture, edited by Charles T. Little, 110-111. New York: Metropolitan Museum.

Jung, Jacqueline E. 2015. "The Portal of San Vicente Martír in Frías: Sex, Violence, and the Comfort of Community in a Thirteenth-Century Sculpture Program at The Cloisters." In Theologisches Wissen und die Kunst, edited by Rebecca Müller, Anselm Rau and Johanna Scheel. 369-382. Berlin: Gbr. Mann Verlag.

Karge, Henrik. 1995 [1989]. La catedral de Burgos y la arquitectura del siglo XIII en Francia y España. Valladolid: Junta de Castilla y León.

Lozano, Esther. 2003. "La portada de Santo Domingo de Soria. Estudio formal e iconográfico" PhD diss., Universitat Rovira i Virgili.

Mariño, Beatriz. 1989. "'Judas mercator Pessimus': Mercaderes y peregrinos en la imaginería medieval." In Los Caminos y el Arte: actas: VI Congreso Español de Historia del Arte: CEHA: Santiago de Compostela, 16-20 de Ju- nio de 1986, 31-41. Santiago de Compostela: Universidade de Santiago de Compostela.

Martín Viso, Iñaki. 2000. Poblamiento y estructuras sociales en el norte de la Península Ibérica:(Siglos VI-XIII). Salamanca: Ediciones Universidad de Salamanca.

Martínez de Aguirre, Javier, and Asunción de Orbe Sivatte. 1987. "Consideraciones acerca de las portadas lobuladas medievales en Navarra. Santiago de Puente la Reina, San Pedro de la Rúa de Estella y San Román de Cirauqui," Principe de Viana 48, no. 180: 41-60.

Martínez Díez, Gonzalo. 1982. Fueros locales en el territorio de la provincia de Burgos. Burgos: Caja de Ahorros Municipal de Burgos.

Martínez Ruiz, Maria José. 2008. La enajenación del patrimonio en Castilla y León (1900-1936). Valladolid: Junta de Castilla y León.

Monsalvo Antón, José María. 1999. “Los territorios de las villas reales de la vieja Castilla, ss. XI-XIV: antecedentes, génesis y evolución. (Estudio a partir de una docena de sistemas concejiles entre el Arlanza y el Alto Ebro)." Studia historica. Historia medieval 17: 15-86.

Moreno Alcalde, María P. 2003. "Puertas del cielo. El arco lobulado en el arte medieval español." Goya: Revista de arte 295-296: 225-244.

Oroz Reta, José. 1978. "Sancti Braulionis Caesaraugustani episcopi Vita sancti Aemiliani." Perficit, 9: 165-215.

Porter, Arthur K. 1969 [1928]. Spanish Romanesque Sculpture. New York: Hacker Art Books.

Poza Yagüe, Marta. 2004. “La portada historiada en Castilla y León del Románico pleno al Tardorrománico y estilo 1200." PhD diss., Universidad Autónoma de Madrid.

Quintana, Celestino. 1887. Historia de la Ciudad de Frías. Vitoria: Establecimiento Tipográfico de Casiano Jáuregui.

Rico Camps, Daniel. 2010. "Reflexiones sobre la decantación hispana de la escultura borgoñona." In Maestros del románico en el Camino de Santiago coordinado por Pedro Luis Huerta Huerta., 119-149.Aguilar de Campoo: Fundación Santa María la Real. 
Rodríguez Montañés, José Manuel. 2002. “Vallejo de Mena." In Enciclopedia del Románico en Castilla y León. Burgos, dirigido por Miguel Ángel García de Guinea y José María Pérez González, Aguilar de Campoo: Fundación Santa María la Real, 2089-2107.

Rorimer, James. 1963 [1938]. The Cloisters: the building and the collection of Medieval Art in Fort Tyron Park. New York: Metropolitan Museum of Art.

Ruiz Maldonado, Margarita. 1986. El caballero en la escultura románica de Castilla y León. Salamanca: Universidad de Salamanca.

Sánchez Ameijeiras, Rocío. 1994. "Notas sobre un arca sepulcral gótica conservada en el museo arqueológico nacional." Boletín del Museo Arqueológico Nacional 12, no. 1-2 :103-112.

Sánchez Ameijeiras, Rocío. 2002. “Imagery and Interactivity: Ritual Transaction at the Saint's
Tomb." In Decorations for the Holy Dead. Visual embellishment on tombs and shrines of saints edited by Stephen Lamia y Elizabeth Valdez del Alamo, 21-38. Turnhout: Brepols.

Silva y Verástegui, Soledad de. 1993. "Miniaturas inéditas de la "Vida de San Millán de la Cogolla" en un códice del siglo X." Berceo 124: 61-66.

Ubieto Arteta, Aurelio. 1965. "Los Votos de San Millán." In Homenaje a Jaime Vicens Vives (I),309-324. Barcelona: Universidad de Barcelona.

Ubieto Arteta, Aurelio. 1976. Cartulario de San Millán de la Cogolla: (759-1076). Valencia: Anubar. (SMI)

Villasante, Agustín. 1944. Historia de la Ciudad de Frías. Buenos Aires: Talleres gráficos de Olivieri y Domínguez. 